\title{
The Mercurialineae and Adenoclineae of South Africa.
}

BY

\author{
D. PRAIN, C.I.E., F.R.S.
}

Director of the Royal Gardens, Kere.

\section{INTRODUCTORY.}

$\mathrm{T}$ a former paper (Ann. Bot., xxv. $575^{-638)}$ the writer, in reviewing the 1 Euphorbiaceous genera Erythrococca, Benth., and Micrococca, Benth., discussed a suggestion made by Baillon in 1862 (Adansonia, iii. 167-76) that these two genera, with Claoxylon, A. Juss., Adenocline, Turcz., and Seidelia, Baill., are referable to Mercurialis. There is little to add to the reasons given in I9II for adopting another view. But as a revision of Erythrococca and Micrococca was called for then ${ }^{1}$ when preparing the 'Flora of Tropical Africa', so now, in preparing the 'Flora Capensis', a similar revision is required of Seidelia and Adenocline, and of certain South African species included in $\mathrm{I} 862$ by Baillon in Mercurialis, but transferred in 1866 to two new genera, Leidesia and Paradenocline, proposed (DC. Prodr., Xv: 2, 792; II4I) by Müller.

\section{History OF MERCURIALIS PROCUMBENS.}

When Linnaeus dealt with Mercurialis in the first edition of the 'Species Plantarum' in I 753 only his fourth species, $M$. procumbens, Linn. (Sp. Pl., ed. I, 1036), was African. The earliest reference to this species is over half a century older; it was one of the plants obtained in South

1 Since that revision appeared one doubtful point has been cleared up. It was stated (Ann. Bot., xxv. 605) that Claoxylon sphaerocarpum, O. Kuntze (Rev. Gen. Pl., iii, 2, 248), almost certainly belongs to some other genus. Through the kindness of Dr. N. L. Britton, Director-in-Chief, New York Botanic Garden, we have seen the original specimen; it is really Croton sylvaticus, Hochst. Since I9I I it has been necessary to describe two new species of Micrococca: M. scariosa, Prain (Kew Bulletin, I9I2, I92), an East African species representing a new section; and M. lancifolia, Prain (Kew Bulletin, I9I2, 282), a Madagascar plant most nearly allied to the South-east African M. capensis. To the synonyms of the genus Micrococca must be added Mercurialis $\S$ Trismegista, Endl. (Gen. Pl., IIII [1840]); to those of the species M. Mercurialis, Benth., should be added Ricinokarpos indica glabra Mercurialis folio, Burm. (Thes. Zeyl., 205 [1737]). From a recent contribution to African botanical literature by Dr. Mildbraed (Wiss. Ergebn. Deutsch. Zentr.-Afr. Exped., I907-8, ii. $45^{2}$ [1913]) we learn that Dr. Pax now treats Claoxylon $\S$ Discoclaoxylon, Müll. arg., as a distinct genus Discoclaoxylon, Pax, and that he also treats Claoxylon § Athroandra, Müll. arg., as a distinct genus Athroandra. Both decisions, as has been explained (Ann. Bot., xxv. 596,605), though permissible, are really unnecessary; the latter, however, had been, with a defect of orthography, anticipated by Pierre (Fl. Trop. Afr., vi. I, 868). The generic name used by Pierre and by Pax is not permissible; if the group Athroandra be treated as a genus the name to be used is Chloropatane, Engl.

[Annals of Botany, Vol. XXVII. No. CVII. July, 1913.] 
Africa and grown at Leiden which Hermann intended to figure; in his posthumous catalogue of 1698 it was named Mercurialis africana dicoccos, folio violae tricoloris (Par. Bat., App. 10). In I720 Boerhaave included this plant in his genus Ricinokarpos (Ind. alt. Lugd.-Bat., i. 254) as R. afra: Mercurialis procumbens, dicoccos, Africana, folio violae tricoloris, thus modifying Hermann's name and adding the epithet 'procumbens'. In 1737 Burmann, in his list of Hermann's African plants (Thes. Zeyl., App. I6), again modified Hermann's name by shortening it to Mercurialis africana, minor, lucida.

The plant which bore these names at Leiden is known from specimens in the British Museum (Natural History) collection written up by Gronovius as 'Ricinocarpus afra, B. Ind. I, 254 syn. Mercurialis procumbens dicoccos africana folio violae tricoloris, Par. B., Ap. Io H'. The same herbarium includes another specimen of the plant from Clifford's garden. Linnaeus did not enumerate the species in the 'Hortus Cliffortianus' in I737, and the legend with this specimen, 'Ricinocarpus afra Mercurialis Linn. Gen. 910 afra', which must date from after 1742 , was not written by him. But the species was apparently accounted for in the 'Viridarium Cliffortianum' in $\mathrm{I} 737$; in I 740 Royen (Fl. Leyd. Prodr., 203) recorded $M$. androgyna, Linn. (Virid. Cliff., 98), as being Hermann's African Mercurialis-Boerhaave's African Ricinokarpos. Moreover, in I753 (Sp. Pl., ed. I, I036) Linnaeus not only accepted Royen's identification of $M$. androgyna, Linn., with Boerhaave's African 'Ricinokarpos'; he substituted for his own term 'androgyna' the word 'procumbens' which Boerhaave had intercalated in Hermann's name. Besides, in I753 and again in I755, Linnaeus, as Dr. Jackson has shown the writer, noted the presence in his own herbarium of the plant whose name had thus been changed from $M$. andogyna to $M$. procumbens.

When Boerhaave defined Ricinokarpos he characterized it as a genus with 3 -coccous capsules, and included in it two species. The first of these, $R$. afra, which is Mercurialis procumbens, Linn., he did not describe in full; we know, however, that its capsules are 2-coccous, and that it does not accord with the generic definition. The second species, which Boerhaave named ' $R$. americana flore albo spicato folio circaeae acutiori', was raised at Leiden from seed collected by Hartog between Berbice and Surinam. This species has 3 -coccous capsules, and does accord with the generic definition. This latter plant appears to have been lost at Leiden between I720 and I737; it is not included in the Cliffortian 'Hortus' or 'Viridarium' of 1737 , or in Royen's 'Prodromus' of 1740.

The circumstance that Ricinokarpos, Boerh., was a complex of two genera led to some misunderstanding. Possibly because the only part of Ricinokarpos which he knew was the African part, Linnaeus in 1737 (Gen. Pl., ed. I, 307) reduced Boerhaave's genus to $75^{6}$ Mercurialis, Tournef., 
remarking that the plant he had in mind differs from the European species in being androgynous. Later in the year J. Burmann published his 'Thesaurus Zeylanicus'; in an appendix thereto (Cat. Afr. Pl. Herm., I6) the African Mercurialis of Hermann, which had been treated by Boerhaave as the first species of Ricinokarpos, was referred to Hermann's genus, not to that of Boerhaave. In the body of the work (Thes. Zeyl., 204) the name Ricinokarpos was restricted by Burmann to that part of Boerhaave's genus which is represented by Hartog's 3 -coccous plant from Surinam; his account of Ricinokarpos indica hirsuta foliis Urticae vulgaris fructus in parvis acetabulis gerens ends with the remark 'tricoccum adeoque omnia ut in Ricinokarpo Boerhavii cujus notas vide definitas in ejus Ind. H. L. Bat.'

The ancipital nature of Boerhaave's genus was also realized by Royen, who followed Linnaeus in associating Boerhaave's name Ricinokarpos with the 2-coccous African species and suggested that the new generic name which was necessary should be applied to the 3 -coccous American species. Linnaeus before the close of 1737 adopted this suggestion, and published the proposed new genus (Coroll. Gen., I9), on Royen's authority, as 986 Acalypha: Ricinocarpos, Boerh. Burm. 92. This arrangement did not disturb the citation of Ricinocarpos, Boerh., under $75^{6}$ Mercurialis in the 'Genera ' itself ; it was repeated and regularized in 1742 (Gen. Pl., ed. 2, 456), when 865 Acalypha, Roy., was given as the equivalent of Ricinocarpos, Boerh. Burm. 92, while under 910 Mercurialis, Tournef. (1. c., 48I), was still cited Ricinocarpos, Boerh., by implication now only so far as the 2-coccous African species was concerned. ${ }^{1}$ This arrangement, though immediately convenient, did not alter the facts that the African portion of Ricinokarpos, Boerh., belongs to a genus apart from Mercurialis; that it is the American portion of Ricinokarpos, Boerh., which alone agrees with Boerhaave's generic definition, and was alone entitled to Boerhaave's generic name; and that the identification of Ricinokarpos, Burm., as based on the plant figured at t. 92 of the 'Thesaurus', with Ricinokarpos, Boerh., as based on Hartog's species from Surinam, was not justifiable. Apart from these drawbacks, however, the establishment of Acalypha, Roy., made the situation intelligible ; all that was required to regularize it was the formal transfer, as $A$.Ricinocarpos, of Hartog's Surinam species to the genus of which Royen had made it the basis. Unfortunately when, in 1753 , the opportunity for this arrived, Linnaeus omitted the Surinam plant from the first edition of the 'Species Plantarum'. When, in 1764 , he did deal with Hartog's plant, instead of referring it to the

1 The object Linnaeus had in view when he adopted Royen's genus Acalypha appears to have been the suppression of a generic name which was exposed to the risk of ambiguity. Kuntze (Rev. Gen. Pl., ii. 615) has, however, interpreted the action of Linnaeus differently. According to Kuntze, Royen allowed Linnaeus to use him as a 'dummy', while 'die Verdrängung von Ricinocarpus Burm. durch Acalypha L. "Royen" war ein offenbares Unrecht von Linné gegen seinen früheren Chef Burmann'. The facts of the case do not, however, seem to bear out this somewhat severe conclusion. 
genus that Royen had based upon it, Linnaeus placed it in Croton as C. Ricinocarpos, Linn. (Sp. Pl., ed. 2, I427). Had the repudiation of Royen ended here our inquiry into the African Mercurialineae would not have been affected. But Linnaeus, in trying to place the Surinam portion of Ricinocarpos, Boerh., on a surer footing, obscured the identity of the African part. He balanced his omission of the American species in 1753 by the elision in 1763 of his own Mercurialis procumbens. This was to carry reparation too far; though, even so, small harm need have happened had not Linnaeus endeavoured to account for the references under the African species. Two citations, Hermann's of 1698 and Boerhaave's of 1720 , were transferred to Solandra capensis, Linn. (Sp. Pl., ed. 2, 1407), the other two, his own of I 737 and Royen's of 1740, were repeated under Croton Ricinocarpos. Since the names of Hermann, Boerhaave, and Royen connote the same species it was inevitable that Linnaeus should find his action as regards the synonyms of Hermann and Boerhaave unsatisfactory. His personal copy of the second edition of the 'Species Plantarum' shows that, prior to I 77I, he struck his pen through both; the plant he had described as Solandra capensis proved to be a Hydrocotyle, which was republished in $\mathrm{I} 78 \mathrm{I}$ by the younger Linnaeus (Suppl. Pl., I76) as H. Solandra. Another home was sought for the unlucky synonyms; they were cited in I77I (Mantiss. Pl., 298) under a new species collected in South Africa by Koenig and described as Mercurialis afra, Linn. Again the citation proved unsatisfactory; again the plant turned out to be a Hydrocotyle. In his own herbarium, Linnaeus struck his pen through the name Mercurialis afra, and wrote the sheet up afresh as Hydrocotyle villosa. The specimen is now in the Hydrocotyle cover, where it was laid by Linnaeus ; the name, published in $178 \mathrm{I}$ by his son (Suppl. Pl., I 75), was unaccompanied by the synonyms of Hermann and Boerhaave, which Linnaeus thus left homeless after all.

The plants of Solander and Koenig, identified in succession with Hermann's African Mercurialis, Boerhaave's African Ricinocarpos, at any rate came from the Cape; in each case, when he realized that these plants belonged to another genus, Linnaeus abandoned the synonyms. But the reduction of his own Mercurialis androgyna to his own Croton Ricinocarpos involved the assumption that $M$. androgyna differed generically from the African plant of Hermann and Boerhaave, and that it was a native of Surinam. The name $M$. androgyna, as used by Royen in I740, connoted that African plant and no other; this new citation by Linnaeus involved therefore a further repudiation of Royen. As, however, Royen was cited by Linnaeus along with himself, this repudiation, though undeniable, is manifestly unintentional. It is, therefore, more than probable that, even when he wrote Croton Ricinocarpos where he ought to have written Acalypha Ricinocarpos, Linnaeus did not really desire to discredit Royen.

In the absence of any specimen written up by Linnaeus as 'Mercurialis 
androgyna', it is arguable that $M$. androgyna, Roy. (Fl. Leyd. Prodr., 203), the African plant of Hermann and Boerhaave, may have differed from $M$. androgyna, Linn. (Virid. Cliff., 98), and that the latter, since Linnaeus says so, really was the Surinam Ricinokarpos of Boerhaave. This is to contend that we must concede that Linnaeus knew his own species, and that therefore we must accept his identification. The argument is plausible, and in its favour is the consideration that it influenced an author so careful as Müller, who (DC. Prodr., xv. 2, 798) has quoted $M$. androgyna, Linn., as the equivalent of 'Croton Ricinocarpus, Linn. quoad syn. Boerh. et patriam Surinamiam'. But the argument is less weighty than it appears; it can only be employed at all if the period at which Linnaeus's recollection was most vivid be treated as negligible. The word 'androgyna', as used by Linnaeus in 1737 , is not a nomen triviale in the sense conveyed by the specific epithets first employed in 1753 ; it is only an apt condensation of the note appended to the generic definition of $75^{6}$ Mercurialis (Gen. P1., ed. I, 307) of the same year. The association of Royen with Linnaeus in 1737 was so close that even under ordinary circumstances Royen was unlikely to have used the name $M$. androgyna in 1740 for a plant other than that so named by Linnaeus only three years before. The circumstances in this case were, however, unusual. In 1737 Linnaeus found himself in a difficulty through his having failed to observe what Burmann did observe, that Ricinokarpos, Boerh., is an ancipital genus. That difficulty centred in the statement by Linnaeus that the plant which is Mercurialis androgyna, Roy., was also the basis of Ricinokarpos. Later in the year, Linnaeus adopted a suggestion made by Royen which overcame the difficulty. The acceptance of Müller's identification involves, then, the assumption that by 1740 Royen had fallen into error as regards the name applied in 1737 by Linnaeus to the plant to whose existence the difficulty that Royen had solved was due. The intrinsic improbability of Müller's hypothesis is heightened by the existence of a Cliffortian specimen which certainly is $M$. androgy'na, Roy. (I840), and must either be M. androgyna, Linn. (I737), or be a plant from Clifford's garden for which Linnaeus failed to account. An examination of the contents of the Mercurialis cover in the Linnean herbarium disposes of the suggestion that the recollection of Linnaeus as to the identity of his $M$. androgyna of 1737 was clearer in 1763 , when he referred it to Croton as C. Ricinocarpos, than it was in 1753 , when he referred the same plant to Mercurialis as $M$. procumbens.

In that Mercurialis cover five species are represented. Three of these have been written up by Linnaeus himself as-I, perennis; 2, annua; 3 , tomentosa. These represent respectively the three species so named in I 753 (Sp. Pl., ed. I). Another has been written up by Linnaeus, without a serial number, as androgyna, this word being afterwards struck through by him and the name ambigua substituted. The reason for this change is 
apparent; the plant is androgynous, so that the deleted name is suitable; but it is a European not an African one, and therefore is neither the plant which Royen in 1740 believed to be $M$. androgyna, Linn., nor the plant which Linnaeus himself in 1763 believed to be $M$. androgyna, Linn. Like the species numbered $\mathrm{I}, 2$, and 3 , this unnumbered plant is fully accounted for; it is the species published in 1763 (Sp. Pl., ed. 2, $146^{6}$ ) as $M$. ambigua, Linn. The last species in the Mercurialis cover is upon a sheet headed by Linnaeus, in larger script, MERCURIALIS ; at foot, with a pencil ' 4', he has written in ink 'Croton', and then struck this through in order to substitute Mercurialis in his usual hand. To this last endorsement Sir J. E. Smith, in pencil, has added 'procumbens, Sp. Pl., ed. I, I036', and also 'Croton Ricinocarpos, Sp. Pl., ed. 2, I427', with a further memorandum that these determinations were based upon specimens in herb. Banks. The specimen to which these various annotations refer belongs to the South African plant of Hermann and Boerhaave. It was in the Linnean herbarium in 1763 ; though it is not a native of America, and therefore cannot be Boerhaave's Surinam Ricinokarpos, this specimen, the expression 'caulis pollicaris' indicates, is that on which the brief account of Croton Ricinocarpos was based. While this much is certain, it is also probable that the reference of the species to Croton instead of to Acalypha may be a lapsus due to the presence of the cancelled name 'Croton' on the sheet. There is, at any rate, little room for doubt that this name 'Croton' was struck through and the name 'Mercurialis' substituted when the first edition of the 'Genera Plantarum' was under preparation. The circumstance that Linnaeus, though he did not write up the sheet as 'procumbens', did write it up as ' 4 ' makes it almost certain that the species on this sheet is really the fourth Mercurialis of 1753 , and that Smith, on the strength of the Cliffortian and Gronovian specimens of the same plant in herb. Banks, was as fully justified in treating this Linnean specimen as the type of Mercurialis procumbens, as he was in considering it the type of Croton Ricinocarpos.

The subsequent history of this species has been uneventful. As Mercurialis procumbens it was neglected until, in I 866 (DC. Prodr., xv. 2, II4I), Müller, with less than his customary caution, placed it in the newly founded genus Paradenocline. As Croton Ricinocarpos, Linn., it was taken up by Aublet in 1775 (Pl. Guyan., 883) ; by Willdenow in 1805 (Sp. Pl., iv. I, 551); by Geiseler in 1807 (Croton. Monogr., 66); and by Sprengel in I 826 (Syst. Veg., iii. 877). These authors, following Linnaeus or each other, all failed to note that the plant they were dealing with bears little resemblance to that described by Boerhaave, or to observe that it is an African species to which the locality and the citation from Boerhaave cannot apply. In I 82 I Steudel apparently noticed that Croton Ricinocarpos could hardly be a Croton, for he suggested (Nomencl., ed. I, 524) the resuscitation of the name Mercurialis androgyna. This was not necessary, 
because, as Richter showed in 1840 (Cod. Linn., 952), M. androgyna of 1737 and the suppressed $M$. procumbens of $\mathbf{I} 753$ must be identical.

The evidence available shows that $M$. androgyna, Linn. (Virid. Cliff., 98) of I737, M. procumbens, Linn. (Sp. Pl., ed. I, I036) of 1753, and Croton Ricinocarpos, Linn. (Sp. P1., ed. 2, I427, quoad diagn. tantum) of 1763 are identical. It shows that the two last are based on the same specimen, and it suggests that this specimen, which, alone among those he could then have owned, supplied the evidence in support of the note of Linnaeus under $75^{6}$ Mercurialis in 1737 , may also be a co-type of the species named $M$. androgyna in the same year.

Müller, whose conclusions have been generally accepted, in I 866 decided that all three are different. According to him $M$. andrggyna, Linn., is Croton Ricinocarpos, Linn., so far as Boerhaave's American Ricinokarpos and the locality Surinam are concerned, whereas Croton Ricinocarpos, Linn., as to the plant described, but excluding Boerhaave's American synonym and the locality Surinam, is identical with Leidesia capensis, Müll. arg. (DC. Prodr., xv. 2, 763), also (1. c., 699) named L. Sonderiana. These conclusions seem incompatible. In identifying Croton Ricinocarpos with Leidesia capensis, Müller has excluded Boerhaave's American synonym and the Surinam plant, thus leaving Mercurialis androgyna as part of his species (1. c., 793); further on (1. c., 798) Müller has cited M. androgyna, Linn., as being Boerhaave's Surinam plant. Whereas Linnaeus had included under Croton Ricinocarpos, Linn., both his own M. androgyna and Boerhaave's Surinam Ricinokarpos, Muiller excluded first the one and then the other, thereby implying, no doubt unintentionally, that the African species to which the description of Croton Ricinocarpos applies is a tertium quid. Muiller's reference to the specimen in the Linnean herbarium must not be interpreted as implying that the name quoted was written up by Linnaeus : in citing Smith's identification of the plant as the basis of Croton Ricinocarpos, Muiller has not mentioned Smith's simultaneous identification of the same specimen as Mercurialis procumbens. On the contrary, instead of agreeing with Smith that, because they are based on the same specimen, Mercurialis procumbens and Croton Ricinocarpos must be identical, Müller has cited the two names under two distinct genera.

This then completes the story of the 2-coccous African plant included by Boerhaave in $\mathrm{J} 720$ in his 3 -coccous genus Ricinokarpos, which in I866 became the basis of Müller's distinct and valid genus Leidesia, Müll. arg. The history of the 3-coccous American plant on which, from his description, we learn that Boerhaave meant to base Ricinokarpos, and on which we know that Royen in I 737 based the genus Acalypha, has yet to be written; no one has identified any particular Surinam plant as being that named by Boerhaave 'Ricinokarpos americana; flore albo spicato folio circaeae acutiori'. 
The considerations which influenced Royen when he made this plant the basis of the genus Acalypha have already been explained. Seeing that this is the plant to which alone the generic definition of Ricinokarpos formulated by Boerhaave applies, the action suggested by Royen and adopted by. Linnaeus was perhaps unfortunate. Burmann (Thesaur. Zeyl.) showed a better appreciation of the case when he maintained Boerhaave's name Ricinokarpos, and strove to establish effectively the genus that Boerhaave had in view. With this object Burmann added to Ricinokarpos seven 3 -coccous species, all, as Burmann believed, members of Boerhaave's genus. Unfortunately, as Kuntze has pointed out (Rev. Gen. Pl., ii. 6I 5), Ricinokarpos, Burm., instead of being precisely equivalent to the American portion of Ricinokarpos, Boerh., is a mélange of three genera. The first of Burmann's seven species, which is figured (Thesaur. Zeyl., t. 92), is a Tragia; the sixth is the species treated by Endlicher in 1840 as the basis of Mercurialis $\S$ Trismegista (Gen. Pl., I II I), and made by Bentham in I 849 the type of the genus Micrococca (Hook. Niger. Fl., 5०3); the other five, of which the last is also figured (Thesaur. Zeyl., t. 93, Fig. I), do belong to what Royen identified with the genus Ricinocarpos, Boerh., as represented by the Surinam plant collected by Hartog. Boerhaave so defined Ricinokarpos that we know which of the two species therein included is the type of his genus. Burmann provided no generic definition; it cannot, therefore, be said with certainty which of the three genera that he included in Ricinokarpos best interprets his conception. It was on this account incumbent on Linnaeus to treat the first species, which Burmann had figured (Thesaur. Zeyl., t. 92), as the type of Ricinokarpos, Burm. But this plant is very different from Ricinokarpos, Boerh., which is also the type of Acalypha, Roy. ; it is, in fact, a Tragia, so that the identification by Linnaeus (Coroll. Gen., I9) of Ricinokarpos, Burm., with Ricinokarpos, Boerh., is not intelligible. ${ }^{1}$ It is then remarkable to find an authority on matters of the kind so competent as Kuntze, after an accurate statement and a careful discussion of the facts, arriving at conclusions (Rev. Gen. Pl., ii. 6I5) which these facts appear to controvert. Thus Kuntze has said that because Linnaeus supposed that Ricinokarpos, Burm., is identical with Ricinokarpos, Boerh., therefore Acalypha, Roy., being a homonym of Ricinokarpos, Boerh., must be reduced to Tragia, Linn., of which Ricinokarpos, Burm. non Boerh., is a homonym. Further, Kuntze has said that, because Burmann did apply the name Ricinokarpos to certain species which appear to be congeneric with Ricinokarpos, Boerh., it is, therefore, necessary to employ-Kuntze says 'to reinstate' - the genus 'Ricinocarpos, Burm.'

As regards the former conclusions: Acalypha, Roy., is a part-the

1 What is practically the converse of this curious confusion was caused by Thunberg in $\mathbf{I} 794$ (Prodr. Pl. Cap. I4) when he published as Tragia capensis a species of Ctenomeria, Harv., and as T. villosa a species of Acalypha, Roy. 
3-coccous part-of Ricinokarpos, Boerh.; no part of Ricinokarpos, Boerh., is referable to Tragia, Linn.; therefore Acalypha, Roy., is not referable to Tragia, Linn. As regards the latter conclusion: Linnaeus was compelled to treat Ricinokarpos, Burm., as represented by the species placed first in order by Burmann under his genus and figured at t. 92 of the 'Thesaurus Zeylanicus'. This plant is a member of the genus Tragia, Linn., which has priority; the use of the name Ricinocarpos, Burm., advocated by Kuntze, is therefore precluded.

It would have been satisfactory if Royen had emulated Burmann in an effort to retain the name Ricinokarpos for the genus which Boerhaave intended so to characterize. But a generous regret that this was not done cannot alter the circumstance that, even when the criteria recognized by Kuntze in respect of the determination of the priority of generic names are observed, the genus Acalypha, Roy., remains properly characterized and validly established.

\section{Additional South African Mercurialineae.}

The next Mercurialis after that of Hermann to be reported from South Africa was $M$. annua, Linn., recorded by N. L. Burmann (Fl. Cap. Prodr., 27. bis [3I]) in I768, and again by Thunberg (Prodr. Pl. Cap. 78 ) in I794 and (Fl. Cap. ed. Schult., 387) in 1823 . Müller in I 866 ignored both Burmann's record of $\mathrm{I} 768$ and the similar record by Baillon made (Adansonia, iii. I $5^{8}$ ) in 1862 ; Thunberg's record he disposed of by reducing $M$. anmua, Thunb. non Linn., to Leidesia capensis, Müll. arg. (DC. Prodr., xv. 2, 793). Had Burmann's statement been of a general character, some confusion between $M$. annua and Leidesia capensis might well have been suspected, and Müller's caution in accepting this South African record of a European species would have been natural. But the statement is a precise one; Burmann saw the Cape specimen of $M$. annua, Linn., in the herbarium of Oldenland, who, as we know from the elder Burmann, ${ }^{1}$ gave especial attention to introduced plants already established at the Cape in 1737 .

As regards the treatment accorded to Thunberg it has to be observed that there is nothing in what Thunberg says of $M$. annua which could prevent his plant from being the Linnean one, and the only sheet of

1 To his Thesaurus Zeylanicus the elder Burmann attached two catalogues of Cape plants. The first of these, already quoted, which occupies pp. I-23, enumerates the Cape plants of Hermann; the second, pp. 24-34, enumerates the Cape plants collected by Oldenland and by Hartog. The final page of this catalogue is devoted to Plantae Exoticae in Capite Bonae Spei aeque laete germinantes ac in earum Patria. The fact that there is no Mercurialis enumerated in this catalogue of Oldenland's Cape plants, and yet that there was a Mercurialis from the Cape among the specimens in Oldenland's herbarium, leaves us with little doubt that Oldenland considered this Mercurialis to be only an exotic species in the Cape Peninsula. It is not mentioned in the actual list of exotic species alluded to. But this is not surprising; that list is confined to plants of economic or aesthetic interest, and does not include garden- or field-weeds like $M$. annua. 
$M$. annua in herb. Thunberg, which Müller has examined, and which, through the kindness of Professor Juel, the writer has also seen, shows that Müller's identification needs to be qualified. There are on Thunberg's sheet of $M$. annua two specimens; though he has written up both as $M$. annua, they belong to two species. One of the two has also been written up, correctly, by Müller as $M$. anmua; the other, which Müller has written up as Leidesia Sprengeliana, is Mercurialis procumbens, Linn., and is what Müller later described as L. capensis. The reduction of $M$. annua, Thunb., to L. capensis, Müll. arg., involves the assumption that, of the two plants on his sheet, Thunberg had the Leidesia more particularly in view. This assumption, however, is not justifiable. Besides mixing two species on the sheet, Thunberg at one time had become confused with regard to their provenance; the sheet, on the reverse, is endorsed, by Thunberg himself, 'e Japonia Thunberg'. This proves that when he wrote this legend Thunberg knew that the specimens had been gathered during his travels. Neither species grows in Japan; Thunberg realized this in time, for he did not include $M$. anmua in his 'Flora Japonica'. The Leidesia specimen could only have been gathered in South Africa; there is no reason for supposing that its companion was gathered anywhere else. Müller, in 1866 , had the less justification for ignoring the genuine $M$. anmua specimen in herb. Thunberg, because in 1862 Baillon (Adansonia, iii. I 58) had recorded the presence in herb. Jussieu of a Cape specimen of $M$. annua named Urtica capensis ${ }^{1}$ by Lehmann in ${ }^{1} 83^{2}$. There is, however, a stronger reason for believing that by $M$. annua Thunberg really intended the Linnean plant, and that the admixture of Leidesia capensis, Müll. arg., was fortuitous. We find in South Africa a second Leidesia, so closely allied to L. capensis that it only differs in having smaller capsules and seeds, rather fewer stamens, and rather fewer teeth on the leaf-margin. Yet this species, first described by Thunberg (Fl. Cap. ed. Schult., 546) in 1823 , was published, not as a Mercurialis, but as an Acalypha, A. obtusa, Thunb. ${ }^{2}$ The doubt

1 Baillon (1.c.) states that this specimen is a 'Un. it.' one ; that is, a specimen of the 'Württemb. Reise-Verein' also known as the 'Naturhist. Reise-Verein zu Esslingen' or the 'Esslinger ReiseVerein'. This 'Verein' was founded by Steudel and Hochstetter in I 826 (Flora, ix. I, 87). In 1832 it advertised (Flora, xv。2, 406): 'Cap-Pflanzen gesammelt von Ecklon und herausgegeben v. d. Württembergischen Reiseverein, gekauft I 829. 692 sp.' In I 829 (Flora, xii. I, II 3 ) we find it announced that the 'Reiseverein' had just received a collection containing some three hundred species made by Ecklon of Cape Town. Lehmann's Urtica capensis is no doubt one of the species alluded to in that notice.

2 The specimen of this plant, written up by Thunberg himself as Acalypha obtusa, is the basis of Leidesia obtusa, Müll. arg. (DC. Prodr., xv. 2, 793). According to Steudel in 184I (Nomencl., ed. 2, i. 10), the name used by Sprengel when he took up this plant was the variant A. obtusata. No doubt, in intention, $A$. obtusata, Spreng., and $A$.obtusa, Thunb., are identical. But, in practice, Sprengel caused his name to cover not only Leidesia obtusa, Müll. arg. ( = Acalypha obtusa, Thunb.), with 2 -coccous capsules, but also a species with 3 -coccous capsules treated by Müller as the basis of a distinct genus Paradenocline (1. c. II $4 \mathrm{I}$ ) which was in 1880 merged by Bentham in Adenocline, Turcz. To this genus Adenocline belongs another species described by Thunberg (Fl. Cap., ed. Schult., 546) as Acalypha acuta, though in his herbarium he has written up some of the 
felt by Müller has, however, been dispelled by Schlechter and by Kässner, who since $\mathrm{I} 866$ have found that $M$. anmua is present, as an introduced weed of cultivated ground, in the Cape and the Tulbagh divisions of the Coast region of South Africa. It is, however, to be noted that the Outeniqua locality given by Thunberg for $M$. annua (ed. Schult., $3^{87}$ ) must relate to the Leidesia, which does occur in woods, not to the Mercurialis, which is only to be found in fields and gardens.

The next Mercurialis recorded from South Africa was $M$. triandra, E. Mey., a very distinct species described in 1829 (Linnaea, iv. 237) from specimens collected within the Orange River catchment area by Drège. This is the species which in $185^{8}$ was treated by Baillon (Etud. gén. Euphorb., 465, t. 9, fig. 7) as the basis of his genus Seidelia. Drège's other species of Mercurialis from South Africa were not enumerated till 1843 (Zwei Pfl. Documente, 20I), where, in addition to M. triandra, E. Meyer has recorded $M$. annua?, Drège, and $M$. tricocca, E. Mey. The former is not $M$. annua, Linn.; it has a quincuncially imbricate in place of a valvate male calyx and a 3 -coccous in place of a 2-coccous capsule, so that it is not even Mercurialineous. Curiously, the other species, M. tricocca, E. Mey., is in intention, and partly in practice, the same species with 3 -coccous capsules and imbricate male calyx-lobes. But along with this nonMercurialineous plant Meyer issued as M. tricocca both the Leidesia which Linnaeus had named Mercurialis procumbens and the one which Thunberg had named Acalypha obtusa.

The same year, 1843 , saw the publication by Meissner (Hook. Lond. Journ. Bot., ii. 556-9), from specimens obtained by Krauss, of four species of Mercurialis, which, as they have 3-coccous capsules and imbricate calyxlobes, are not Mercurialineae but belong to Adenocline, Turcz. They were enumerated again by Krauss himself in 1845 (Flora, xxviii. 84) with the addition (1. c., 85) of $M$. tricocca, on this occasion as limited by Ecklon and Zeyher to the plant with imbricate calyx and 3 -coccous capsules, and without the confusion created by Meyer. In 1846 Kunze raised at Leipzig, from Cape seed sent by Zeyher, this same species, for which he provided a new name, $M$. violaefolia (Ind. Sem. Hort. Bot. Lips. MDCCCXLvi, c. diagn.). ${ }^{1}$ This 3 -coccous plant he described more fully in 1847 (Linnaea, $\mathrm{xx} .55$ ), along with another raised from South African seed, which he had issued as $M$. Zeyheri, but which he now believed (1. c., 54) might be Meissner's M. bupleuroides. This latter plant, though undoubtedly, like Meissner's

sheets so described as $A$. glabrata. This species, according to Steudel, was taken up by Sprengel as Acalypha acuta. In 1843, however, when establishing the genus Adenocline, Turczaninow (Bull. Soc. Imp. Nat. Mosc., xvi. I, 59) altered its trivial name 'acuta' to 'Mercurialis'.

1 It appears possible that Kunze, in using this name, may have been subconsciously influenced by the idea that the plant designated might be Hermann's Mercurialis africana dicoccos folio violae tricoloris. It certainly much resembles Hermann's species in externals, but the imbricate calyx and the 3 -coccous capsules show that it is not the same plant. 
one, an Adenoctine, differs sufficiently from $M$. bupleuroides to justify the use of the name $M$. Zeyheri.

Besides the Urtica capensis, already referred to, which is Mercurialis annua, Linn., there was distributed a second Urtica capensis (Un. It. 8 I 4 , Eckl.), which is Mercurialis procumbens, Linn. We learn from Ecklon and Zeyher, in 1847 (Linnaea, xx. 2I3), in connexion with Zeyher's 3844 from Table Mountain, that Sprengel had altered the name of this second Urtica capensis to Mercurialis capensis, which, they further suggest, may be only E. Meyer's $M$. tricocca. It is not what was intended by E. Meyer as $M$. tricocca, because its capsules are 2-coccous. But it was in practice mixed by E. Meyer with $M$. tricocca, and we learn from Sonder that Sprengel fell into the converse error and mixed $M$. tricocca with it. In removing these misapprehensions Sonder, in $185^{\circ}$ (Linnaea, xxiii. I I I, I I2), provided brief diagnoses, restricting the name $M$. tricocca, E. Mey., to the plant on which, in I866, Müller was to base his genus Paradenocline, and similarly restricting the name $M$. capensis, Spreng., to the plants on which, in I866, Müller was to found his genus Leidesia. Sonder at the same time added to our debt by adequately diagnosing, as $M$. pumila, Sond., one of the species on which, in 1858 , Baillon was to base the genus Seidelia. But Sonder's work is not free from defects. In the first place he overlooked the fact that the characters of $M$. tricocca are essentially those of his own genus Diplostylis (1. c., I 13), which is a homonym of Adenocline, Turcz. Again, though he did notice that his $M$. capensis appeared variable, he did not observe that it really included two species. Lastly, through some misapprehension, he identified $M$. tenella, Meissn., which belongs to his own 3 -coccous genus Diplostylis, with $M$. triandra, which is a 2-coccous species most closely related to his own $M$. pumila.

In $185^{8}$ Baillon based on $M$. triandra, E. Mey., and $M$. pumila, Sond., the valid Mercurialineous genus Seidelia, and treated all the species of Mercurialis enumerated by Krauss in I 845 as members of Turczaninow's genus Adenocline. In so doing he used Thunberg's specific name 'acuta' for the species which Turczaninow had termed $A$. Mercurialis, but maintained Turczaninow's name for the species termed $M$. tricocca by E. Meyer. As to this Baillon further followed Meyer's practice and included (Etud. gén. Euphorb., 457) along with M. violaefolia, Kunze, which is an Adenocline, both of the species on which, eight years later, Müller was to found the genus Leidesia.

The year I 862 was marked by the appearance of Baillon's classical paper (Adansonia, iii. I69-76), in which all the forms reported from South Africa that are referable to the Mercurialineae and to the Adenoclineae were once more treated as species of Mercurialis. The action was less drastic, perhaps, than it appears; Baillon admitted the existence, within his widened genus, of five distinct sections. In dealing with the species from 
South Africa which are referred to this widened genus (l. c., iii. I $5^{8-60}$ ), Baillon followed Sonder almost too closely, for under $M$. capensis he still included the two species of Leidesia, while under M. triandra he repeated Sonder's misapprehension as regards $M$. tenella. While properly adopting Kunze's name, $M$. violaefolia, in place of E. Meyer's name, $M$. tricocca, Baillon has attributed the former name to E. Meyer ; under $M$. bupieuroides he has quoted $M$. annua, Drège, which is really $M$. violaefolia. His treatment of the species in the Adenocline section, as we shall find when dealing with that genus, is even more unsatisfactory.

The treatment of the sections was, after all, only an amplification of that proposed by Endlicher (Gen. Pl., IIII) in 1840. Endlicher's Mercurialis, which included $M$. alternifolia, Lamk. (= Micrococca Mercurialis, Benth.), was subdivided into a Linozostis, with leaves opposite and capsules 2 -coccous $=$ the true Mercurialis, Linn.; and $\beta$ Trismegista, with leaves alternate and capsules 3 -coccous $=$ Micrococca, Benth. In enumerating the South African species, Baillon placed in Linozostis only $M$. anmua, Linn. In Trismegista Baillon placed two species: (1) M. capensis, which, while it is not a Linozostis because its leaves are mostly alternate, is not a Trismegista because its capsules are 2-coccous; and (2) $M$. violaefolia, which, although it has 3 -coccous capsules, cannot be a Trismegista because its male calyx-lobes are imbricate and its styles are 2-partite. To Endlicher's two sections Baillon added a section Adenocline, with 3-coccous capsules, divided styles, and imbricate calyx-segments, a section Seidelia, with 2-coccous capsules and cruciately 4-valved anthers, and, lastly, a section Erythrococca with, as was then erroneously believed, indehiscent fruits. All of these sections are natural groups; they are, indeed, valid genera. The only one of the five in respect of which Baillon, in dealing with the Cape species, was at fault is his Trismegista, which in the first place does not include any species really belonging to that section as limited by Endlicher, and, further, is a mixture of two genera, Leidesia and Adenocline. In the synoptic summary which follows his general paper (Adansonia, iii. I75), Baillon departed from this arrangement to the extent of reducing Adenocline as a whole to Trismegista, an unfortunate afterthought, seeing that Adenocline is not a member of the group Mercurialineae, and does not belong to the sub-tribe Acalypheae or Dysopsideae. Notwithstanding its imperfections, Baillon's treatment supplies the basis for a review of the situation. The number of South African forms referable to Mercurialis, as extended by Baillon in I862, was known to be twelve. One of them is $M$. annua, Linn., which calls only for mention in passing; it is a true Mercurialis, but it is only an alien weed at the Cape. Four of the others agree with Mercurialis proper in having 2-coccous capsules, simple styles, and a valvately partite male calyx; the remaining seven differ from Mercurialis proper in having 3 -coccous capsules, 2-partite styles, and a quincuncially imbricate male calyx. 
All four 2-coccous forms deviate from Mercurialis proper in having alternate leaves and in being normally monoecious. Two of the four, which have firm opaque leaves, only 2-3 anthers, and quite glabrous capsules, differ further from Mercurialis in having cruciately 4-valved mature anthers. These became the basis in $185^{8}$ of the valid genus Seidelia, Baill. The remaining two, which have flaccid, pellucid leaves, $4-7$ stamens with only 2-valved anthers, and hispidulous capsules, though generically distinct, had not so far been separated either sectionally or generically from Mercurialis, except when in 1858 , and then, perhaps, only by accident, Baillon referred them to Adenocline. ${ }^{1}$

One of the 3-coccous forms with a 2-partite style and imbricate male calyx-lobes agrees with the two preceding forms in having flaccid, pellucid leaves and in being monoecious. This was, in $185^{8}$, referred by Baillon, but only in company with the two preceding forms, to Adenocline; it was not so treated by Turczaninow, and Sonder, whose Diplostylis is a homonym of Adenocline, left this monoecious species in Mercurialis as $M$. tricocca. The remaining six 3 -coccous forms with 2-partite styles and imbricate calyx-lobes have firmly herbaceous leaves and are dioecious. They constitute the genus Adenocline, Turcz. (I843): Diplostylis, Sond. (I850).

None of the three forms with flaccid, pellucid leaves have ever been confused with Seidelia. They have, however, been much confused in books and in herbaria among themselves. In three instances-by E. Meyer under the name Mercurialis tricocca, by Sprengel under the name M.capensis, and by Baillon under the name Adenocline Mercurialis-all three have been treated as belonging to the same species. More often, however, the existence of two species among the forms with flaccid, pellucid leaves has been admitted. In literature-as, for example, by Sonder and by Baillon-it has been the custom to distinguish between a species with 2-coccous capsules, termed $M$. capensis, and another species, with 3-coccous capsules, termed by Sonder $M$. tricocca, by Baillon $M$. violaefolia. As a consequence, the species described by Thunberg as Acalypha obtusa has never, in any published work, been separated from the species described by Linnaeus as Mercurialis procumbens. In collections, however, the confusion has been somewhat different. Nearly allied as Acalypha obtusa and Mercurialis procumbens are, they are easily sorted out and have rarely been laid into herbaria side by side. On the other hand, in spite of their differing as regards their stamens-central in Acalypha obtusa, peripheral and 2-seriate in $M$. violaefolia ; their capsules-2-coccous in the former, 3 -coccous in the latter; their styles-simple in the first, 2-partite in the second; and their male calyces - valvately partite in one, quincuncially imbricate in the

1 As Adenocline Mercurialis, which Baillon attributed to Turczaninow, but which did not include Turczaninow's species so named, though it did include Mercurialis procumbens, Linn., Acalypha obtusa, Thunb., and Mercurialis violaefolia, Kunze. 
other-these two plants so closely resemble each other that even in the field the most careful of collectors have at times been led astray.

To Müller our thanks are due for having, in 1866 , determined this double confusion. He rectified matters by establishing the genus Leidesia for the reception of $M$. capensis, Sond., and at the same time by distinguishing as L.obtusa the somewhat elusive species which, as to bibliography, had hitherto been merged in its 2-coccous congener, but, as to practice, was in herbaria mainly to be met with in the covers containing the 3 -coccous South African species with flaccid, pellucid leaves. This last species, with androgynous inflorescences, 3 -coccous capsules, 2 -partite styles, and imbricate calyx-lobes, Müller treated as a distinct genus, Paradenocline, Müll. arg., most nearly allied to Adenocline, Turcz. When doing so, Müller pointed out that these two genera, Adenocline and Paradenocline, conjointly form a distinct and natural group, which he named Adenoclineae and referred to the sub-tribe Hippomaneae (DC. Prodr., Xv. 2, I I39).

The recent history of these South African groups has not been eventful. It has, however, been found necessary to add to Leidesia a new species, L. firmula, Prain (Kew Bulletin, I912, 337), and to Adenocline another new species, A. stricta, Prain (1. c., 338).

\section{Review of SEIDELia.}

The genus Seidelia was established by Baillon in $185^{8}$ (Étud. gén. Euphorb., 465, t. 9, fig. 7) for two South African species till then included in Mercurialis. One of these, first collected by Drège in the Orange-Vaal basin, is $M$. triandra, E. Mey. (Linnaea, iv. 237), published in 1829; the other, found by Zeyher in the Coast Region of Cape Colony, is M. pumila, Sond. (Linnaea, xxiii. I I 2), published in 1850 . In I 862 Baillon replaced Seidelia, as a distinct section, in Mercurialis (Adansonia, iii. I60, I75).

When dealing with Seidelia in I 866 (DC. Prodr., xv. 2, 947) Müller differed from Baillon in two respects. Müller treated the two species accepted by Baillon as varieties of one; at the same time he transferred the whole section 'Seidelia' from Mercurialis to Tragia. The only apparent reason for this transfer is that Seidelia and Tragia normally have each three stamens. The transfer was not accepted by Hooker in I 868 (Harv. Gen. S. Afr. Pl., ed. I, 338) ; it was repudiated by Bentham in 1880 (Gen.

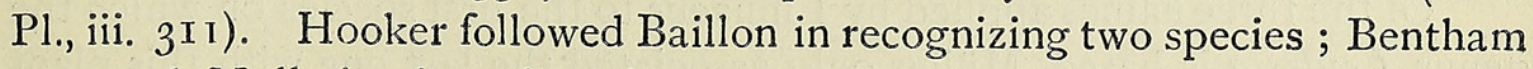
accepted Müller's view that there is but one variable Seidelia. For this view there was as little ground as there was for the transfer of Seidelia to Tragia. Bentham has stated that Seidelia is closely allied to Adenocline; the differences between the two as regards flowers, to which Bentham was fully alive, make this statement as hard to accept as Müller's view that Seidelia is closely allied to Tragia. There is, no doubt, a general similarity between some species of Adenocline and certain species of Mercurialis; 
there is a close affinity between Mercurialis and Seidelia. But between Adenocline and Seidelia there is little external resemblance and even less affinity; Adenocline belongs to the Gelonieae, Seidelia to the Acalypheae.

The nearest relationship of Seidelia is with the genus Leidesia. Both agree with Mercurialis in their simple styles, 2-coccous capsule, and valvately partite male calyx; both differ from Mercurialis in having alternate, not opposite leaves; both are usually monoecious, Mercurialis is usually dioecious. They differ from each other because in Seidelia the anthers are cruciately 4 -valved and the female calyx and hypogynous discglands are well developed, while in Leidesia the anthers are 2-valved and the female calyx and hypogynous disc-glands are usually small or obsolete. In Seidelia the capsules are glabrous; in Leidesia they are setulose.

\section{REVIEW OF LEIDESIA.}

The genus Leidesia was founded by Müller in I 866 (DC. Prodr., xv. 2, 792) to include two South African species. One is the plant which Linnaeus named Mercurialis androgyna in $1737, M$. procumbens in 1753, and Croton Ricinocarpos in 1763 . The other is the plant described by Thunberg in 1823 as Acalypha obtusa (Flor. Cap., ed. Schult., 546). The history of the first species has been recounted. The second species has a brief history; it never was formally transferred from Acalypha. This, however, is not because the plant is an Acalypha, but because Sonder in $185^{\circ}$ (Linnaea, xxiii. 112) and Baillon in 1862 (Adansonia, iii. $15^{8}$ ) did not separate these two South African congeners. ${ }^{1}$

Since the word Leidesia is an anagram of the name Seidelia (DC. Prodr., xv. 2, 793) it is probable that, when he devised the name Leidesia, Muiller thought Seidelia a valid genus, the transfer of which to Tragia was a sudden, as well as an unhappy afterthought. A possible sequel of this afterthought is the citation by Müller under Leidesia of 'Mercurialis, sect. Seidelia, Baill., Rec. d'obs. bot., vol. 3, p. $15^{8}$ pr. p. et p. I 75 pr. p.' (1. c., 792). This reduction contradicts the citation of 'Mercurialis, sect. Seidelia' as a whole, under Tragia, sect. Seidelia (1.c., 947). That the citation at p. 792 is a lapsus we learn from a third passage (1. c., I 14I) where the correct name 'Mercurialis, sect. Trismegista' is used.

Of the three names applied by Linnaeus to the first species on which the genus Leidesia is based, Müller only associated the last one with this plant with 2-coccous capsules; the first name he associated with an American, the second name with an African species, both of which have 3 -coccous capsules. Even as regards the third name Müller decided that it must be set aside.

1 In 1843 E. Meyer (Drège, Zwei Pfl. Documente, 201) also aggregated the two species of Leidesia, and united both with a 3 -coccous plant which he had named Mercurialis tricocca. The same amalgamation was repeated by Baillon in $185^{8}$ (Étud. gén. Euphorb., 457) under the name Adenocline Mercurialis, Baill. non Turcz. 
When he examined the South African sheet of Mercurialis anmua in herb. Thunberg, Muiller wrote up the portion which belongs to Leidesia as $L$. Sprengeliana. This name, however, he altered to $L$. Sonderiana (DC. Prodr., xv. 2, 699), and as a further afterthought changed to L. capensis, Müll. arg. (1. c., 793). These earlier tentative names indicate that the term 'capensis' was taken up by Müller from Sprengel and from Sonder, who in turn had taken it up from specimens collected on Table Mountain by Ecklon and issued (Un. It. 8I4) as Urtica capensis, Thunb. Sonder in 1850 (Linnaea, xxiii. II2) assumed that this identification was correct, and further, relying upon Thunberg (Flor. Cap., ed. Schult., I 55), assumed that, if the plant really were $U$. capensis, Thunb. (Prodr. Pl. Cap., 3I of 1794), it must also be $U$. capensis, Linn. f., of $\mathrm{I} 78 \mathrm{I}$ (Suppl. Pl., 4I 7 ) and of $\mathrm{I} 784$ (Syst. Veg., ed. I4, 850). Baillon in I862 (Adansonia, iii. $15^{8}$ ) realized that caution was needed in connexion with this name, and showed that one 'Un. It.' specimen, named U.capensis, Thunb., by Lehmann, is Mercurialis annua, Linn. But while dealing appropriately with this plant, Baillon accepted Sonder's verdict as regards Ecklon's n. 8I4, and in this he was followed by Müller in I 866. Baillon quoted Thunberg and copied from him the Linnean citation of $\mathrm{I} 784$; Müller quoted Thunberg and copied from him the Linnean citation of $178 \mathrm{I}$. But neither Baillon nor Müller examined the specimens in the Urtica covers in the herbaria of Thunberg and of Linnaeus. As a consequence, both Baillon and Müller have failed to observe that the Mercurialis capensis of Sprengel and Sonder and Baillon (Leidesia capensis, Müll. arg.) has no more to do with Urtica capensis, Thunb., or with $U$. capensis, Linn. f., than these two plants have to do with each other.

The specimen which forms the basis of Urtica capensis, Linn. f. (Suppl. P1. 4I 7), was presented by Thunberg to Linnaeus, without a name, after the appearance of the second Mantissa in I77I. The specimen was written up by Linnaeus, in his usual hand, as ' $T$. 326 ' and as 'Urtica africana'; it is in the Urtica cover in the Linnean herbarium now (Jackson, Ind. Linn. Herb. 148). The description was not published until after the death of Linnaeus; when publishing it, the younger Linnaeus, possibly by accident, altered his father's name 'africana' to capensis. The specimen is a good one; the description is apt; the plant is the one which has been treated by Müller (DC. Prodr., xv. 2, 864) as Acalypha decumbens, $\alpha$ villosa. The endorsement ' $T$. 326 ' having been written by Linnaeus, not by Thunberg, suggests that the number was not bestowed on the specimen by Thunberg. In any case, Thunberg was not able to decide what, among the plants he had presented to Linnaeus, the species which the younger Linnaeus had described as Urtica capensis might be. The duplicate kept by Thunberg himself of the specimen now in the Urtica cover of the Linnean herbarium which is the type of U.capensis, Linn. f., was used by Thunberg as the type of 
Tragia villosa, Thunb. (Prodr. P1. Cap., I4, and Flor. Cap., ed. Schult, 37), while $U$. capensis, Thunb., is altogether different. The specimens of Urtica in herb. Thunberg, kindly lent for study by Professor Juel, show that under $U$. capensis there are two sheets written up as 'capensis $\alpha$ ' and 'capensis $\beta$ ' respectively. On the 'capensis $\alpha$ ' sheet we find two plants; one of the two, which agrees with the description, is Australina capensis, Wedd. (Ann. Sci. Nat., sér. 4, i. 212 (I854)); the other is Droguetia Thunbergii, N. E. Brown (Kew Bulletin, I9I3, 80). ${ }^{1}$ The sheet marked 'capensis $\beta$ ' has only Australina capensis, Wedd.

The relationship of Leidesia to Seidelia, and of both to Mercurialis, we have already learned ; the three genera taken conjointly constitute a distinct group, the Mercurialineae, ${ }^{2}$ characterized by its valvately partite male calyx, its simple styles, and its 2-coccous capsule.

\section{REview of PARADENOCLINE.}

The genus Paradenocline was proposed by Müller in I866 (DC. Prodr., xV. 2, II4I) to include a South African species with all the facies of a Leidesia, which nevertheless had to be excluded not only from that genus but from the subtribe Acalypheae in which Leidesia is placed, because the species in question has a quincuncially imbricate male calyx and has 2-partite styles. So far as can be ascertained, this species was first collected by Drège in the neighbourhood of Paarl. From E. Meyer we learn that Drège, when he first found the plant, thought that he had met with the European Mercurialis annua. In 1843 E. Meyer issued the Paarl specimens of this species under Drège's name. But Drège collected the same plant at Addo in Uitenhage, and we learn from specimens of this gathering written up in herb. Lübeck, that this is the species to which E. Meyer intended to restrict the name $M$. tricocca, also issued for the first time in 1843 . Actually, however, in 1843 Meyer included under his $M$. tricocca not only this 3 -coccous species but both of the species of Leidesia in which the capsules are 2-coccous, the styles are simple, and the male calyces are valvately partite. From Sonder we learn that some time prior to $185^{\circ}$ Sprengel

1 Droguetia Thunbergii, N. E. Brown, is similarly mixed in herb. Thunberg with Urtica caffra, Thunb. (Prodr. Pl. Cap., 3I ; Flor. Cap., ed. Schult., I 55). Under this species, again, two sheets have been written up as 'caffra $a$ ' and 'caffra $\beta$ ' respectively. The 'caffra $a$ ' sheet has Droguetia Thunbergii, N. E. Brown, only; with this plant, however, the description of U. caffra does not tally. The 'caffra $\beta$ ' sheet has a plant with which Thunberg's description of $U$. caffra exactly agrees. This plant is another species of Australina, which must therefore be known as A. caffra. When Weddell monographed the Urticaceae he had not seen this type specimen in herb. Thunberg, because he suggested (DC. Prodr., xvi, I, 60) that $U$. caffra, Thunb., may be Fleurya peduncularis, Wedd., and because he has described the species which is $U$. caffra, and which therefore must be known as Australina caffra, under the name A. acuminata, Wedd. (Ann. Sci. Nat. sér. 4, i. 2 I 2 $(1854))$.

2 The name Mercurialineae is here employed in a more restricted sense than that understood by Pax (Nat. Pflanzenf., iii. $5,4^{6}$ ). 
had written up the same aggregate of three species and two genera as $M$. capensis. In 1858 Baillon renamed the same conglomerate Adenocline Mercurialis, using this name in a sense different from that in which it was employed in 1843 by Turczaninow.

Though it was not recognized that Meyer in 1843 had used two names, $M$. annua, Drège non Linn., and M. tricocca, E. Mey., for the same plant, it was soon noticed that more than one plant had been issued under the name $M$. tricocca, and we learn from Krauss that by 1845 Ecklon and Zeyher had already restricted the incidence of the name $M$. tricocca to the species with 3 -coccous capsules. Sonder in 1850 (Linnaea, xxiii. I I I) adopted what had been Meyer's intention and Ecklon and Zeyher's usage; by providing a brief diagnosis of the plant Sonder for the first time made it possible to cite Meyer's name. But Sonder's action was too late to effect its purpose. In 1846 Kunze had applied to the same species the name $M$. violaefolia (Ind. Sem. Hort. Bot. Lips. MDCCCXLvi, c. diagn.), and in 1847 had described it more fully under the same name (Linnaea, xx. 55). Kunze again referred to the species as $M$. violaefolia in $185 \mathrm{I}$ (Linnaea, xxiv. I62); it is under this name therefore that Baillon accounted for the species in 1862 (Adansonia, iii. I59). There is nothing to indicate that Kunze suspected his Mercurialis violaefolia to be what Drège had mistaken in the field for $M$. annua, or to be what E. Meyer intended to indicate and Krauss did indicate by $M$. tricocca. But the name employed by Kunze does suggest that, whether he believed the two plants to be identical or not, he had gone to Hermann's phrase Mercurialis africana dicoccos folio violae tricoloris for the idea which his own specific epithet conveys. The description given by Kunze is so careful-the only serious error is the statement that the styles are entire-that it is most unlikely that he should have thought his 3 -coccous species identical with the 2 -coccous plant of Hermann. The name selected by Kunze had, however, a curious aftereffect.

When Müller first referred to the species on which his Paradenocline was based (DC. Prodr., xv. 2, 793) he adopted from Baillon the name used by Kunze, and termed the plant $P$. violaefolia; as an afterthought (1.c., I I4I) Müller treated as a certainty the idea which Kunze's name 'violaefolia ' suggests. Since Kunze's name may have been based on Hermann' name, and since Linnaeus has cited Hermann's plant under $M$. procumbens, Müller decided that $M$. violaefolia, Kunze, and $M$. procumbens, Linn., are identical, and that the name Paradenocline violaefolia, Müll. arg., must be replaced by the name $P$. procumbens. ${ }^{1}$ Even if the premisses had been sound, the conclusion could not have been sustained ; $P$. procumbens, Müll. arg., is a species which does not occur in the Linnean herbarium, and has not been

1 On p. 793 both names are used-P. procumbens in the note under the generic description of Leidesia, $P$. violaefolia in that under the account of $L$. obtusa. 
referred to in any of the writings of Linnaeus ; the plant which Linnaeus in I753 did term Mercurialia procumbens is a species of Leidesia.

When founding the genus Paradenocline in I 866 Müller indicated its affinity to Adenocline, Turcz., to which genus Baillon in $185^{8}$ had, after a fashion, transferred its solitary species. Muiller treated the two genera as constituting a distinct group, the Adenoclineae, founded by him in I 865 (Linnaea, xxxiv. 203) and characterized by its circumferentially inserted stamens and certain other characters. From Adenocline Müller distinguished Paradenocline because in the latter the anther cells are at first pendent as in Mercurialis itself; he made no use of the erroneous character of entire styles which he had copied from Kunze. Bentham may have observed that this latter difference was non-existent; he believed the former character to be at least inconstant, and decided in 1880 (Gen. Pl., iii. 310 ) to revert to the view adopted by Baillon in $185^{8}$. In this Bentham was followed by Pax in 1890 (Nat. Pflanzenf., iii. 5, 49). This action is, however, somewhat too drastic and may, in part at least, have been encouraged if not induced by an error into which Bentham has been betrayed in his statement that Adenocline, Turcz., is a monoecious genus. The flaccid, pellucid foliage, the annual habit, and the androgynous inflorescences render Paradenocline, Müll. arg., so different from Adenocline, Turcz., that the claim of the former to rank as, at least, a distinct section is not open to dispute.

\section{REview of AdENOCLINE.}

The genus Adenocline was established by Turczaninow early in I 843 (Bull. Soc. Imp. Nat., Mosc., xvi. I, 59) to include some South African species collected by Drège and Zeyher. Only one of these was known before 1843 . This is the plant which Thunberg in his herbarium wrote up as Acalypha glabrata, but which was described in 1823 (Flor. Cap., ed. Schult., 546) as $A$. acuta, Thunb., a name repeated by Steudel in I84I (Nomencl., ed. 2, i. I0).

When in 1843 E. Meyer referred what is Paradenocline, Muill. arg., to Mercurialis, he did not name any of the plants that Turczaninow included in Adenocline. Later in 1843 Meissner described as species of Mercurialis specimens of most of the species of Adenocline. That Meissner had not seen Turczaninow's paper is shown by his reference under $M$. bupleuroides to specimens collected by Drège and cited by Turczaninow. By way of compensation there appeared in 1844 (Flora, xxvii. I2I) a résumé of Turczaninow's paper. Continuing the seesaw, Krauss, who had collected most of the specimens alluded to by Meissner in I 843 , gave a résumé of Meissner's paper in I 845 (Flora, xxviii. 84) without observing that he was dealing with Turczaninow's genus, and without the attention of the editor of 'Flora' being attracted to this fact. It is clear that Turczaninow's paper was unknown to Kunze in 1847 , when he dealt, as a species of Mercurialis, 
with an Adenocline raised at Leipzig from South African seed (Linnaea, xx. 54). It was still unknown to Sonder when in I 850 (Linnaea, xxiii. I I3) he published as Diplostylis, Sond., the genus already established as Adenocline, Turcz.

So long as this neglect of his more accurate observation only involved the inclusion of Adenocline in Mercurialis, Turczaninow was under no obligation to re-enter the field. Lamarck in I796 (Encyc. Meth., iv. I20) had recognized as a species of Mercurialis a plant with alternate leaves and 3 -coccous capsules; Endlicher in 1840 (Gen. Pl., III I) had founded a distinct section for its accommodation. All the South African species which Meissner, Krauss, and Kunze had treated as species of Mercurialis agree with $M$. alternifolia, Lamk., as regards their capsules, and all but one do so as regards their phyllotaxis. So long as they could feel that an imbricate in place of a valvate calyx, and 2-partite in place of a simple style were negligible differences, Meissner and Krauss and Kunze were at liberty to conclude that any Adenocline might be referred to Endlicher's Mercurialis, sect. Trismegista. When, however, in I 849 Bentham based on Lamarck's species the genus Micrococca (Hook., Niger Flor., 5०3) the raison d'être of Endlicher's Trismegista disappeared, and, notwithstanding the advocacy by Thwaites and others of a different view, the soundness of Bentham's judgement has remained unshaken. The establishment of Micrococca, Benth., rendered the separate generic recognition of the South African 'Trismegistae' of Meissner, Krauss, and Kunze inevitable, though it is possible that when Sonder in $185^{\circ}$ proposed his genus Diplostylis he was as unconscious of this fact as he was of the circumstance that Turczaninow had appreciated the situation seven years before. The publication and acceptance of Diplostylis made it, however, incumbent upon Turczaninow to point out the true state of affairs. This he did in $185^{2}$ (Bull. Soc. Imp. Nat., Mosc., xxv. 2, I79, I80).

In $185^{8}$ Baillon (Étud. gén. Euphorb., 456) accepted Turczaninow's genus and included it in Mercurialis violaefolia, placing Adenocline in his Dysopsideae, a group which includes Acalypha, midway between Mercurialis and Seidelia. In 1862 Baillon modified this view and widened the limits of Mercurialis so as to include Adenocline, Turcz., in the first instance (Adansonia, iii. I59) as a distinct section, but, as an afterthought (1. c., I 75), as an integral portion of Endlicher's section Trismegista. In I866 Müller accepted the genus as limited by Turczaninow and Sonder (DC. Prodr., xv. 2, II 39), placing it and Paradenocline in a distinct group, the Adenoclineae, which he referred to the sub-tribe Hippomaneae. The genus was accepted by Hooker in I868 (Harv. Gen. S. Afr. Pl., ed. 2, 338), by Bentham in I880 (Gen. Pl., iii. 310), and by Pax in 1890 (Nat. Pflanzenf., iii. 5, 49). Hooker did not discuss the limitation or the affinities of Adenocline. Bentham disapproved of Muiller's treatment; like Baillon in 1858 , he 
treated Paradenocline as part of Adenocline; like Baillon also, he replaced the genus in the sub-tribe Acalypheae, between Leidesia and Seidelia. In this Bentham has been followed by Pax, who has placed Adenocline between Erythrococca and Mercurialis. ${ }^{1}$ It is, however, doubtful whether Paradenocline ought not to be given a generic status; there is no doubt that it deserves at least sectional rank, and that its unqualified inclusion in Adenocline is hardly justified. There is no question that any reversion to the view of Baillon that Adenocline is closely related to Mercurialis is a retrograde step. Probably the disregard which recent authors have shown for Müller's facts is traceable to the effect of Muiller's conclusion. In transferring Adenocline and Paradenocline to the Hippomaneae, Müller has shown almost as little consideration for the natural characters of his group as did those authors who have held that Adenocline is a part of, or is allied to, the genus Mercurialis. But the fact that Muiller did not happen to suggest the most suitable position for the Adenoclineae is no excuse for a reversion to a view which Müller had shown to be erroneous, and affords no justification for the suppression of this natural group. The Adenoclineae of Muiller agree so absolutely with the Gelonieae as defined by Bentham (Gen. P1., iii. 253) that their natural situation is not really a matter for debate.

Little difficulty is experienced in separating the species that are to be met with in Adenocline proper. Among the seven species included, one, $A$. acuta, Baill., is at once distinguished from the other six by having opposite leaves. Among the remaining six, one, A. stricta, Prain, has all the leaves sessile, and has large leafy stipules. The other five have at least the lowest leaves distinctly petioled. Two of the five have the upper leaves also petioled; they are $A$. ovalifolia, Turcz., with leafy stipules, and $A$. humilis, Turcz., with minute stipules. Of the three that remain, two, A. sessilifolia, Turcz., and A. Zeyheri, Prain, have the lower petioled leaves narrow-lanceolate; they are distinguished from each other because in A. sessifolia the upper sessile leaves are entire, in $A$. Zeyheri they are serrate. In the last species of our list, $A$. bupleuroides, Prain, at least the lowest and petiolate leaves, sometimes even the upper sessile leaves also, are wide-ovate or orbicular. Simple, however, as the task of discrimination is, there have been difficulties, largely of a bibliographical nature, in accounting for certain names, and in one case, that of $A$. Zeyheri, some real difficulty has been met with in dealing with the actual specimens.

In 1843 Turczaninow enumerated five species, two with opposite leaves, A. Mercurialis (Drège 230I, male) and $A$. panciflora (Drège $344 \mathrm{I}$, both male and female); three with alternate leaves, $A$. ovalifolia (an unnumbered

${ }^{1}$ For some reason Bentham has stated, and Pax has accepted the statement, that Adenocline is a monoecious genus. One of the most characteristic features of Adenocline proper is that all the species are strictly dioecious. Paradenocline is monoecions, but this is one of the circumstances which renders its separate recognition, at least as a section, desirable. 
male plant collected by Zeyher), A. humilis (Drège 8223 , male), and, lastly, $A$. sessilifolia (Drège $\mathrm{I} 867$ and $\mathrm{I} 868$, both male). The second species is a spurious one; in the male specimens the leaves are not opposite, so that this portion has to be excluded from the species $A$. pauciflora and transferred to $A$.humilis, with which it agrees. At the same time the female specimen, which does have opposite leaves and therefore is $A$.panciflora, Turcz., is only the other sex of $A$. Mercurialis, Turcz. The last 'species', $A$. sessilifolia, is a mixture of two distinct plants.

Meissner's species of $\mathrm{I} 843$ were Mercurialis tenella $=$ Krauss II 9 I male $=$ Adenocline humilis, Turcz.; $M$. bupleuroides $=$ Krauss II 69 male, a species unknown to Turczaninow-though Meissner has placed here Drège 1867 definitely and Drège 82,23 doubtfully, these two plants differ specifically from each other and from $M$. bupleuroides; $M$. serrata = Krauss I I 90 male $=A$. ovalifolia, Turcz.; $M$. caffra in two varieties, a brevipes $=$ Krauss I 56 male $=A$. pauciflor, , Turcz., as to description, and $\beta$ longipes $=$ Krauss $\mathrm{II} 92=A$. Mercurialis, Turcz. The treatment by Turczaninow and Meissner is thus singularly uniform. The chief differences are that Meissner found room only for two varieties, $M$. caffra, a brevipes and $\beta$ longipes, where Turczaninow had recognized two species, $A$. pauciflora and $A$. Mercurialis; also that the two authors treated Drège I 867 differently. But in the latter case the discrepancy is apparent rather than real; Turczaninow united Drège $\mathrm{I} 867$ with $A$. sessilifolia, a species unknown to Meissner, while Meissner united Drège I 867 with $M$. bupleuroides, a species unknown to Turczaninow. As a matter of fact, Drège $I 867$ belongs to neither species, but is identical with the one for which, in 1847 , Kunze half-heartedly suggested the name $M$. Zeyheri.

In 1850 Sonder had only four species. The first is Diplostylis angustifolia, and as this includes Drège $\mathrm{I} 868$ it is $=A$. sessilifolia, Turcz. Sonder has cited four gatherings: Drège, I868; Ecklon \& Zeyher, 40; Ecklon \& Zeyher, 39 (Riet Valley); Zuurberg, Zeyher. The last is not in herb. Sonder, and the identification is somewhat improbable. The other three are conspecific. The second species is $D$. bupleuroides; only two gatherings are quoted, in both cases the plant is $M$. bupleuroides, Meissn. Equally simple is $D$. caffra, since all the gatherings cited belong either to $M$. caffra, a brevipes, Meissn., or $\beta$ longipes, Meissn., and all belong either to $A$. pauciflora, Turcz., or to $A$. Mercurialis, Turcz.; but Sonder's treatment is an improvement on that of both Turczaninow and Meissner, since it amalgamates what were two poor species and two indifferent varieties. But the remaining species, $D$. serrata, Sond., is a mélange of two plants. There are in herb. Sonder four specimens to which this name has been attached. One of these is part of 'Ecklon \& Zeyher 39', collected at Swellendam by Mund; another is 'Zeyher 1516', collected by Stack; both of these are A. ovalifolia, Turcz. The third is part of 'Ecklon \& Zeyher 39', gathered 
by these collectors themselves near Uitenhage; the last is 'Drège $1867 a^{\prime}$ ': both of these are Mercurialis Zeyheri, Kunze. Sonder then made the limits of Adenocline sessilifolia natural by excluding Drège 1867 ; he also made the limits of Mercurialis bupleuroides natural by excluding Drège I 867 . But he did so at the expense of his own Diplostylis serrata, which he clearly intended to be identical with Mercurialis serrata, Meisn.=Adenocline ovalifolia, Turcz. In reality $D$. serrata, Sond., is a mixture of $A$. ovalifolia, Turcz., and $M$. Zeyheri, Kunze (Drège I 867).

In overhauling Adenocline in 1852, Turczaninow introduced some improvements. He deleted the spurious $A$. panciflora, so that his $A$. Mercurialis became strictly homonymous with Diplostylis caffra. He removed Drège I 867 from $A$. sessilifolia, so that this species became strictly homonymous with Diplostylis angustifolia. Turczaninow once for all set Drìge I867, which so far had been the invariable stumbling-block, on a sound footing by treating it as the valid species that it is. But from this point onwards fortune was unkind to Turczaninow. He had not seen a specimen of Mercurialis Zeyheri, Kunze, and did not know, any more than Kunze himself did, that this is the species to which Drège 1867 belongs. Turczaninow had not seen any specimen of $M$. serrata, Meissn.; he, therefore, did not know that Meissner's plant is his own A. ovalifolia. Nor did Turczaninow see all the specimens of Diplostylis serrata, Sond.; he therefore did not know that Sonder had confused under this name two unmistakable species. But Turczaninow did possess a specimen of Drège 1867 ; he knew that Sonder had included this in D. serrata. In giving the name Adenocline serrata to Drège 1867 , Turczaninow only did what was natural. But, thanks to this misplaced reliance on Sonder's judgement, Turczaninow's $A$. serrata happens to be that portion of Sonder's Diplostylis serrata which is not the original Mercurialis serrata of Meissner. In the matter of Adenocline humilis Turczaninow was even more unfortunate. Sonder had guessed that Mercurialis tenella, Meissn., was only M.triandra, E. Mey., and therefore not an Adenocline or Diplostylis at all. Turczaninow mistook this surmise for a record of observation and failed to notice that $M$.tenella, Meissn., from the description, must be $A$. humilis, Turcz. Thinking that $M$. tenella really was disposed of, Turczaninow had only $M$. bupleuroides, Meissn., left to account for. He fell a victim to the temptation and identified $M$. bupleuroides with his own $A$. humilis!

The confusion that had grown up between the publication of Adenocline by Turczaninow in 1843 and that author's revision nine years later is, it will be seen, less serious than at first sight appears, and has been due to Meissner and Sonder and Turczaninow having been unable to compare each other's material. The confusion which has taken place since $185^{2}$ is less easy to account for. Baillon in 1858 substituted for the specific names 'Mercurialis' of Turczaninow, and 'caffra' of Meissner and Sonder, the older name 'acuta' 
of Thunberg. This is quite intelligible. What, however, is not intelligible is that Baillon did not treat the name Adenocline Mercurialis, Turcz., as a synonym of $A$. acuta, Baill.; he maintained the name $A$. Mercurialis, ostensibly on the authority of Turczaninow, to connote a mixture of Paradenocline procumbens, Müll. arg., Leidesia capensis, Müll. arg., and L. obtusa, Muill. arg. The use of the name $A$. sessiliftora in place of $A$. sessilifolia is no doubt a mere lapsus. But it is hardly possible to explain the retention of $A$. panciflora, Turcz., after Turczaninow had confessed that no such species exists. Finally $A$. humilis, Baill., which is said to be Mercurialis serrata, Meissn., and if it be so is therefore Adenocline ovalifolia, Turcz., cannot possibly be $A$. humilis, Turcz. In 1862 Baillon treated the five species recognized in 1858 rather differently. All of them were now looked upon as species of Mercurialis; some of them only were placed in the section Adenocline. The $A$. Mercurialis of $185^{8}$ was transferred to the section Trismegista and subdivided into $M$. capensis, corresponding to the genus Leidesia as a whole, and $M$. violaefolia, corresponding to Müller's proposed genus Paradenocline. The other four species were now reduced to three, one of which, M. caffra, is the opposite-leaved Adenocline acuta, Baill., the true $A$. Mercurialis, Turcz., as to the identity and limitation of which mistake is barely conceivable. The non-existent $A$. pauciflora was still kept up as $M$. pauciflora, while all the alternate-leaved species of Adenocline, Turcz., and Diplostylis, Sond., with, in addition, M. annua, Drège non Linn., which is Baillon's own $M$. violaefolia, were lumped together as $M$. bupleuroides, Meissn., the one species described by Meissner of which Turczaninow never saw a specimen.

Only one more step was required to complete the confusion. This Müller took when, in I866, he united the conglomerate 'bupleuroides' and the fictitious 'pauciflora' of Baillon under the name Adenocline panciflora, Müll. arg. (DC. Prodr., xv. 2, II39), thus using for this widened species the one name employed by Turczaninow in 1843 which that author in I852. found it necessary to cancel. That the species thus proposed is a composite one needs no demonstration; Muiller has tacitly admitted the fact by making a careful attempt to separate as varieties the species of Turczaninow, Sonder, and Meissner. In so doing, Müller has not always succeeded in keeping clear of the pitfalls dug by his predecessors; he has, besides, initiated difficulties. Among these may be noted the statement under $\gamma$ humilis that it is the female portion of Drège 344I which is the same as $A$. humilis, Turcz., whereas we know from Turczaninow's statement and from the actual specimens that the female part of Drège 344I has opposite leaves. Müller has referred Drège 1867 both to $\delta$ bupleuroides and to $\zeta$ transiens; the statement that Hout Bay, mentioned under $\epsilon$ serrata in connexion with Krauss II9O, is in Natal is erroneous-the locality is in the Cape Peninsula; the statement under $\theta$ tenella that Krauss II9I is a Natal 
plant is also erroneous-this specimen came from the Humansdorp division of Cape Colony. Again, Zeyher I516, one of the types of Diplostylis serrata, Sond., is cited under $\delta$ bupleuroides, which it does not greatly resemble; while Mercurialis Zeyheri, Kunze, which is identical with $\zeta$ transiens, is cited under $\gamma$ humilis. Finally, $\gamma$ humilis and $\theta$ tenella are the same plant; this is also the case with $\beta$ ovalifolia and $\eta$ serrata. These blemishes, however, are more than compensated for by the advance made by Müller in separating the group Adenoclineae from the group Mercurialineae.

\section{Summary.}

A careful examination of the material available and of the statements made by botanical writers shows that, of the South African species which have from time to time been treated as species of Mercurialis, Linn., only one is really a member of the genus. This species, M. anmua, Linn. (Sp. Pl., ed. i, I०36), is, however, only an introduced weed of cultivated ground which, although evidently already introduced before 1737 , is even yet mostly to be met with in or near the Cape Peninsula. Of the remaining species, about one-third are really Mercurialineae, using this term in a sense somewhat more restricted than that in which it has been employed by Pax (Nat. Pflanzenf., iii. 5, 46); the rest are Adenoclineae, using this term as it was used by Müller (DC. Prodr., xv. 2, I I39). The Mercurialineae, a group within the subtribe Acalypheae, are represented in South Africa by two endemic genera, Seidelia, Baill. (I 858), and Leidesia, Müll. arg. (I866). The Adenoclineae, a group within the subtribe Gelonieae, though more numerous, are referable to a single endemic genus Adenocline, Turcz. (I 843), which, however, includes two distinct sections, one corresponding to the genus Diplostylis, Sond. (I850), the other to the genus Paradenocline, Muill. arg. (I866).

The salient characters of these various groups are as follows:-

I. Mercurialineae [Acalyphearum grex]. Herbs, annual or with persistent base. Calyx closed in bud, valvately lobed. Stamens central; anther-cells subglobose, divaricate. Ovary 2-celled; styles short, entire. Capsule 2-coccous.

I. Mercurialis, Linn. Leaves opposite, herbaceous. Stamens 8-20; anthers 2-celled, 2-valved, cells at first pendulous. Hypogynous disc of 2 linear-subulate scales alternate with the carpels. Inflorescences usually I-sexual, rarely androgynous.-Species 6 ; five European, one Asiatic. One of the European species occurs as an introduced weed in South Africa.

2. Seidelia, Baill. Leaves alternate, herbaceous. Stamens 3 or 2 ; anthers 2-celled, at length cruciately 4-valved; cells ascending. Hypogynous disc of 2 minute glands alternate with the carpels. Capsule glabrous. In- 
florescences usually androgynous, rarely I-sexual.-Species 2, endemic in South Africa.

3. Leidesia, Müll. arg. Leaves alternate, or occasionally opposite or subopposite at the lower branches, usually pellucid and flaccid, rarely herbaceous. Stamens 3-7; anthers 2-celled, 2-valved; cells ascending. Hypogynous disc of 2 minute glands alternate with the carpels, or obsolete. Capsule hispidulous. Inflorescences androgynous.-Species 3, endemic in South Africa.

II. Adenoclineae [Geloniearum grex]. Herbs with persistent base, rarely annual. Calyx quincuncially imbricate. Stamens peripheral, 2-seriate; anther-cells obovoid, divaricate. Ovary 3-celled, with the odd cell posterior; styles slender, 2-partite. Capsule 3-coccous.

4. Adenocline, Turcz. Stamens 6-12; anthers 2-valved. Hypogynous disc of 3 staminodiform glands alternate with the carpels.-Species 8, all endemic in South Africa.

$\S$ Paradenocline, Müll. arg. (gen.). Leaves alternate or occasionally opposite or subopposite at the lower branches, pellucid and flaccid. Anthercells at first pendulous. Inflorescences androgynous.-Species I, annual.

$\S \S$ Diplostylis, Sond. (gen.). Leaves usually all alternate, in one species (A. acuta) all opposite, herbaceous. Anther-cells ascending. Inflorescences always I-sexual.-Species 7 , all with a persistent base.

\section{Mercurialis, Tournef.}

Mercurialis, Tournef. sec. Linn., Gen. P1., ed. I, 307, syn. Boerh. excl. (I737); Thunb., Flor. Cap., ed. Schult., 387 (1823); Benth. in Benth. et Hook. f., Gen. Pl., iii. 309 (I 880); Pax in Engl. \& Prantl, Nat. Pflanzenf. iii. 5, 49, fig. 29 B-D (I 890$)$.

Flores monoici vel casu (M. anmua) dioici, apetali. or Calyx tenuiter membranaceus, in alabastro clausus, globosus vel ovoideus, per anthesin valvatim 3-partitus. Stamina 8-20, centralia, filamentis liberis; antherae terminales, apertae patenter 2-valves; locelli primum penduli. Ovarii rudimentum o. \& Calyx alte 3 -sectus. Discus hypogynus e laminis 2 lineari-subulatis carpidiis alternantibus compositus. Ovarium 2-loculare; ovula in quoque loculo solitaria; styli breves, erecti vel divergentes, intus papillosi, indivisi. Capsula didyma in coccos 2-valves dissiliens, pericarpio membranaceo, endocarpio crustaceo. Semina ovoidea vel globosa; testa crustacea; albumen carnosum ; cotyledones latae, planae.-Herbae annuae vel rhizomate perennante; glabrae vel pubescentes. Folia opposita.

M. annua, Linn., Sp. Pl., ed. 1, I035 (I753); Burm., Fl. Cap. Prodr., 27 bis [31] (1768); Thunb., Prodr. Pl. Cap., 78 (1794), et Fl. Cap., ed. Schult., 387 , quoad descr. sed spp. Outeniq. excl. (1823); Baill., Adansonia, iii. 158 
(1862). Folia firmula, distincte petiolata, ovata, acuta, margine crenata, glabra ; annua.

[VII. a.] South-East Africa : Cape. Coast Region: Cape Div. near Capetown, Oldenland; Thunberg! Lehmann! Schlechter, I364! Tulbagh Div. ; Tulbagh, Kässner, 1287 !

Mercurialis annua, Linn., is a species widely spread in the Mediterranean basin, whence it extends northwards to Central and Western Europe, and westward to Madeira and the Canaries. It appears to have been introduced to South Africa, as a weed, before the middle of the eighteenth century, but even yet it has not become very common or spread very far from the Cape Peninsula.

\section{SEIDELia, Baill.}

Seidelia, Baill., Etud. gén. Euphorb., 465, t. 9, fig. 7 (I $85^{8}$ ); Hook. f. in Harv., Gen. S. Afr. Pl., ed. 2, $33^{8}$ (I868); Benth. in Benth. et Hook. f., Gen. Pl., iii. 3IO (I880); Pax in Engl. \& Prantl, Nat. Pflanzenf., iii. 5, 50, fig. 3I C (I 890$)$.

Mercurialis, E. Mey. in Linnaea, iv. 237 (1829); Sond. in Linnaea, xxiii. II2, pro parte (I850): nec Linn.

Mercurialis $\S$ Seidelia, Baill., Adansonia, iii. I60, I75 (1862).

Tragia § Seidelia, Müll. arg. in DC. Prodr. xv. 2, 947 (I866).

Flores monoici vel casu (S. pumila) dioici, apetali. or Calyx tenuiter membranaceus, in alabastro clausus, depresse globosus, per anthesin valvatim 3-partitus. Stamina 3 vel 2, centralia, segmentis alterna, filamentis basi brevissime connatis ; antherae terminales, apertae cruciatim 4-valves; locelli erecti. Ovarii rudimentum o. \& Calyx brevis, alte 3 -fidus. Discus hypogymus e glandulis 2 parvulis carpidiis alternantibus compositus. Ovarium 2-loculare; ovula in quoque loculo solitaria ; styli breves, recurvi, patentes, indivisi. Capsula parva didyma in $\operatorname{coccos} 2$-valves dissiliens, pericarpio membranaceo, glabro, endocarpio tenuiter crustaceo. Semina ovoidea; testa crustacea; albumen carnosum; cotyledones anguste ovatae.-Herbae annuae, glabrae. Folia alterna.

\section{Clavis SPECIERUm.}

Folia ovato-oblonga, margine crenata, distincte petiolata

Folia lineari-lanceolata vel linearia, margine integra vel utrinsecus I-2-dentata, sessilia vel subsessilia

I. S. pumila.

I. S. pumila, Baill., Étud. gén. Euphorb., 466 (I 858 ). Folia firmula, distincte petiolata, ovato-oblonga, obtusa, margine crenata; annua.-Mercurialis pumila, Sond. in Linnaea, xxiii. II2 (1850); Baill., Adansonia, iii. I60 (1862). Tragia triandra, a pumila, Müll. arg. in DC. Prodr., xv. 2, 947 (1866). 
[VII. a.] South-East Africa: Cape. Coast Region: Uitenhage Div.; at Amsterdamsvlakte between the Coega River and the Zwartkops River, Zeyher, 3843 !

For some reason which is not readily apparent, Müller has treated this species as a variety of the next one.

2. S. triandra, Pax in Engl., Bot. Jahrb., x. 35 (1888), et in Engl. \& Prantl, Nat. Pflanzenf., iii. 5, 50, fig. 3I C (I 89c). Folia firmula, sessilia vel subsessilia, lineari-lanceolata vel linearia, obtusa vel subacuta, margine integra vel prope apicem utrinsecus I-2-dentata.-Mercurialis triandra, E. Mey. in Linnaea, iv. 237 (I829) et in Drège, Zwei Pfl. Documente, 20I (I843); Sond. in Linnaea, xxiii. II3, syn. Meissn. excl. (I850); Baill., Adansonia, iii. I60, syn. Meissn. excl. (I862). Seidelia Mercurialis, Baill., Étud. gén. Euphorb., 466, t. 9, fig. 7 (I858). Tragia triandra, $\beta$ genuina, Müll. arg. in DC. Prodr., xv. 2, 947 (1 866).

[VI.] South-West Africa. Orange-Vaal Basin: Northern Cape Colony: Richmond Div.; Winterveld, near Limoenfontein and Groot Tafelberg, 3000-4000 ft., Drige, 796 ! Hanover Div.; near Hanover, Sim, I3! Griqualand West: Kimberley, Marloth, 869!

\section{LeIdesia, Müll. arg.}

Leidesia, Müll. arg. in DC. Prodr., xv. 2, 793 (1866); Benth. in Benth. et Hook. f., Gen. Pl., iii. 3 Io (I880); Pax in Engl. \& Prantl, Nat. Pflanzenf., iii. 5, 50, fig. 3 I A, B (I890).

Mercurialis, Herm., Par. Bat., App. Io (1698); Burm., Thes. Zeyl., App. I6 (I737); Linn., Gen. Pl. [756], ed. I, 307, quoad syn. Boerh. tantum (I737), et Sp. P1., ed. I, I035, pro parte (I753) ; Sond. in Linnaea, xxiii., pro parte (1850): nec Tournef.

Ricinokarpos, Boerh., Ind. alt. Lugd.-Bat., i. 254, quoad sp. afr. sed diagn. gen. excl. (I720).

Croton, Linn., Sp. P1., ed. 2, 1427, quoad syn. Ricinocarpus, Boerh., partim tantum $(1763)$ : nec Linn. Gen.

Acalypha, Thunb., Pl. Cap., ed. Schult., 546 partim (I 823) : nec Royen.

Adenocline, Baill., Étud. gén. Euphorb., 457, partim (1858): nec Turcz.

Mercurialis $\$$ Trismegista, Baill., Adansonia, iii. I58, partim et quoad M. capensis tantum, I75, partim (1862): nec Endl.

Flores monoici, apetali. or Calyx membranaceus, in alabastro clausus, minute apiculatus, per anthesin valvatim 3 -partitus. Stamina saepius 4- 7 , nonnunquam ( $L$. firmula) 3 , centralia, filamentis basi hinc inde connatis; 
antherae terminales, apertae patenter 2-valves; locelli adscendentes. Ovarii rudimentum 0 . $\quad$ \& Calyx parvus, 3 -fidus, vel obsoletus. Discus hypogynus e glandulis 2 parvulis carpidiis alternantibus compositus vel obsoletus. Ovarium 2-loculare; ovula in quoque loculo solitaria ; styli breves, lineares, indivisi. Capsula parva, didyma, in coccos 2-valves dissiliens, pericarpio membranaceo hispidulo, endocarpio tenuiter crustaceo. Semina subglobosa; testa crustacea; albumen carnosum; cotyledones latae, planae.-Herbae annuae. Folia ad ramificationes opposita vel subopposita ceterum alterna. Bracteae calycibusque maris hispidulae.

\section{Clavis specierum.}

Folia caulibusque firmula, minute crebre crenata, quam lata longiora I. L. firmula. Folia caulibusque flaccida, tenera, fere aeque longa ac lata:-

Folia utrinsecus $4-7$-dentata

2. L. procumbens.

Folia utrinsecus $1-3$-crenata

3. L. obtusa.

I. L. firmula, Prain in Kew Bull., I9I2, 337 (I9 I 2). Herba rigidiuscula, intricatim ramosa. Folia firmula, breve petiolata, ovato-lanceolata vel lanceolata, manifeste longiora quam lata. Stamina 3, raro 4. Flores feminei breve pedicellati.

[VI.] South-West Africa. German South-West Africa: Great Namaqualand; Gamokab, Schinz, 898! Karukab, Schinz, 899! Grootfontein, Dinter, 700 !

A very distinct species.

2. L. procumbens. Herba flaccida, diffuse ramosa. Folia tenera, longe petiolata, deltoideo-ovata, subacuta vel obtusa, margine 4-7-crenata. Stamina saepius 6-7. Flores feminei sessiles.-Mercurialis africana dicoccos, folio violae tricoloris, Herm., Par. Bat., App. Io (1698). M. androgyna, Linn., Virid. Cliff., 98 (I737); Roy., Fl. Leyd. Prodr. 203 (I740) ; Steud., Nomencl., ed. I, 524 (182I). M. africana, minor, lucida, Burm. f., Thes. Zeyl., app. I6 (I737). M. procumbens, Linn., Sp. P1., ed. I, I036 (I753). $M$. annua, Thunb., Fl. Cap., ed. Schult., 387 , quoad loc. Outeniqua tantum (1823): nec Linn. $M$. tricocca, E. Mey. in Drège, $Z$ wei Pfl. Documente, 20I, partim (1843) nomen. $M$. capensis, Spreng. ex Eckl. et Zeyh. in Linnaea, xx. 2 I 3 (I847), nomen; Sond. in Linnaea, xxiii. I I2, syn. Linn. f. et Thunb. excl. (1850); Baill., Adansonia, iii. 158, syn. Linn. et Lehm. excl. (1862). Ricinokarpos; afra, Boerh., Ind. alt. Lugd.-Bat., i. 254 (I 720 ). Croton Ricinocarpos, Linn., Sp. Pl., ed. 2, I427 (1763) ; Aubl., Hist. P1. Guy., ii. 883 (I775) ; Willd., Sp. Pl., iv. 55I (1805) ; Geisel., Crot. Monogr., 66 (I807); Spreng., Syst., iii. 877 (I826) omn. quoad descr. et quoad syn. $M$. androgyna, sed excl. syn. Boerh. et patr. Surinam. Urtica capensis, 
Eckl. Un. It., 8 I 4, ex Sond., 1.c. (1850) : nec Linn. f., nec Thunb. Adenocline Mercurialis, Baill., Étud. gén. Euphorb., 457, partim (18 $\left.5^{8}\right)$ : nec Turcz. Leidesia Sonderiana, Müll. arg. in DC. Prodr., xv. 2, 699 (I866), nomen. L. capensis, Müll. arg., 1. c., 793, sed syn. Urtica capensis, excl. (I 866).

[VI.] South-West AfRica. Transvaal: Houtboschberg, 6,500 ft., Rehmann, 5923! Schlechter, 4427!

[VII. a.] South-East Africa: Cape. Coast Region: Cape Div. ; Table Mountain, Ecklon, 814! Zeyher, 3844! Masson! Wright, 426! Longloof, Dümmer, I376! Devil's Mountain, I,200 ft., Ecklon! Harvey, 504! Bolus, 2941! Wilms, 3623! above Overige Kloof, 2,800 ft., Schlechter, 408! above Groote Schuur, Wolley Dod, 607! George Div. ; Outeniqua Mountains, Thunberg! Roode Muur, Drège (M. tricocca, $\delta)$ ! near George, Burchell, $5^{847}$ ! Moyle Rogers! Knysna Div.; Yzer Nek, Burchell, 5247! Karratera River, Drige (M. tricocca, $\epsilon)$. Albany Div.; without precise locality, Bozvie, I8 ! Stockenstroom Div. ; between Kala and Ugie, 5,000 ft., Bolus, I0284!

[VII b.] Nata1. Griqualand East; Malawe Forest, Tyson, 2 I I 8 ! Natal ; Ismont, 2,000 ft., Wood, I867!

3. L. obtusa, Müll. arg. in DC. Prodr., xv. 2, 793 (1866). Herba flaccida, diffuse ramosa. Folia tenera, longe petiolata, orbiculari-ovata, obtusa, margine I-3-crenata. Stamina saepissime 4-5. Flores feminei sessiles.-Acalypha obtusa, Thunb., Fl. Cap., ed. Schult., 546 (I823); Lehm. ex Baill., Adansonia, iii. I59 (1862). A. obtusata, Spreng. ex Steud., Nomencl., ed. 2, i. 10, pro parte maxima (1840). Mercurialis tricocca, E. Mey. in Drège, $Z_{\text {wei }}$ Pfl. Documente, 20I, pro parte : $a$ partim et $b$ partim (I843): nomen. $M$. capensis, Sond. in Linnaea, xxiii. II2, partim (I850); Baill., Adansonia, iii. ${ }_{5} 58$, quoad syn. Lehm. tantum (1862); Spreng. in Herb. Berol. ex Müll. arg., 1.c. (1866): nec Spreng. ex Eckl. et Zeyh. Adenocline Mercurialis, Baill, Etud. gén. Euphorb., 457, partim (I858): nec Turcz.

[VII a.] South-EAst Africa : Cape. Central Region: Willowmore Div.; Karroo, between the Great $Z$ warte Bergen and Aasvogel Berg, 2,000 ft., Drige (M. tricocca, a in Herb. Kew!) Somerset Div.; between Zuurberg and Bruintje's Hoek, Drige ( $M$. tricocca, $\beta$ in part)! woods at the foot of the Boschberg, 3,000 ft., Macowan, I752! without precise locality, Miss Bowker!

Coast Region: Cape Div.; Shore near Smitswinkel Bay, Wolley Dod, 3302 ! without precise locality, Thunberg! Lehmann! Uitenhage Div.; Zuurberg Range, Drège! Zwartkops River, Ecklon \& Zeyher, 35! near Uitenhage, Prior! Port Elizabeth Div.; Baakens River Valley, Mrs. Paterson, 84I ! Alexandria Div.; near Barville Creek, Burchell, 409I! Albany Div.; Dassie Krantz, Rogers, 396I !

Very nearly allied to L. procumbens, but usually a smaller plant, with decidedly 
smaller capsules and seeds. It bears a close general resemblance to Adenocline (Paradenocline) violaefolia, with which it has frequently been mistaken both in the field and in herbaria.

\section{Adenocline, Turcz.}

Adenocline, Turcz. in Bull. Soc. Imp. Nat. Mosc., xvi. I, 59 (1843), in Flora, xxvii. I2I (1844), et in Bull. Soc. Imp. Nat. Mosc., xxv. 2, I79 (I852) ; Baill., Étud. gén. Euphorb., 456, t. 9, fig. 6 (I858); Müll. arg. in DC. Prodr., xv. 2, II39 (1866) ; Hook. f. in Harv., Gen. S. Afr. Pl., ed. 2, $33^{8}$ (1868); Benth. in Benth. et Hook. f., Gen. Plant., iii. 310 (1880); Pax in Engl. \& Prantl, Nat. Pflanzenf., iii. 5, 49, fig. 30 A-E (I890).

Acalypha, Thunb., Fl. Cap., ed. Schult., 546, partim (1823); Spreng. ex Steud. Nomencl., ed. 2, i. 10 (1840): nec Royen.

Mercurialis, Meissn. in Hook., Lond. Journ. Bot., ii. 556 (1843); Krauss in Flora, xxviii. 84 (1845); Kunze in Linnaea, xx. 54 (1847); Sond. in Linnaea, xxiii. II I, pro parte (I850).

Mercurialis $\S$ Adenocline, Baill., Adansonia, iii. I59 (I862).

Mercurialis \& Trismegista, Baill., 1. c., I58, partim ( $M$. violaefolia tantum) et I 75 pro parte maxima (I862).

Diplostylis, Sond. in Linnaea, xxiii. II3 (I850).

Paradenocline, Müll. arg. in DC. Prodr., xv. 2, I I4I (I866).

Flores dioici, rarissime (A. violaefolia) monoici, apetali. or Calyx membranaceus, alte 5-partitus; lobi quincuncialiter imbricati. Stamina 6-I2, saepissime tamen IO, 2-seriata, circa centrum floris glanduligerum inserta, exteriora cum calycis segmentis alternantia, filamentis liberis; antherae terminales, apertae 2-valves. Ovarii rudimentum $\circ$; glandulae intrastaminales numerosae. \& Calyx parum major, alte 5-partitus; lobi quincuncialiter imbricati: Discus hypogynus e glandulis 3 capitatis staminodiiformibus carpidiis alternantibus compositus. Ovarium 3-loculare, loculi 2 laterali-anteriores, tertius posterior; ovula in quoque loculo solitaria; styli tenues, alte 2-partiti, recurvo-patentes, basi brevissime connati. Capsula parva, 3 -dyma, in coccos 2-valves dissiliens, pericarpio membranaceo glabro, endocarpio tenuiter crustaceo. Semina subglobosa; testa tenuiter crustacea; albumen carnosum; cotyledones anguste ovatae.-Herbae tenues diffusae, saepius basi perennantes ibique sublignosae, raro $(A$. violaefolia) annuae, tenerae. Folia alterna vel raro ( $A$. acuta) opposita; stipulae parvulae vel majusculae. Flores minimi, or saepius plurimi axillares; o singuli opositifolii pedicello subito refracto cymam uniparam efficientes. 


\section{Clavis Specierum.}

Inflorescentiae androgynae; folia tenera, ad ramificationes subopposita, ceterum alterna; annuae [ $\S$ r. Paradenocline]

Inflorescentiae I-sexuales; folia herbacea; perennantes [§ Diplostylis] :-

Folia opposita, longe petiolata

2. A. acuta.

Folia alterna :-

Folia omnia sessilia, ovata, serrata; stipulae majusculae, foliaceae 3. A. stricta.

Folia saltem inferiora petiolata :-

Folia ac superiora ac inferiora distincte petiolata :-

Stipulae majusculae, foliaceae

Stipulae minimae

Folia superiora sessilia vel subsessilia :-

Folia inferiora petiolata orbicularia vel ovata, obtusa

Folia inferiora petiolata auguste lanceolata, acuta :-

Folia superiora sessilia serrata

Folia superiora sessilia margine integra

4. A. ovalifolia.

5. A. humilis.

6. A. bupleuroides.

7. A. Zeyheri.

8. A. sessilifolia.

$\S$ I. PARAdenocline. Caules flaccidi, annui. Folia tenera, longe petiolata, ad ramificationes subopposita, ceterum alterna. Inflorescentiae androgynae. Antherarum loculi demum subreflexi.-Mercurialis, E. Mey. in Drège, Zwei Pfl. Documente, 20I, partim (I843); Krauss, loc. supra cit., 85 (1845); Kunze, loc. supra cit., 55 (I847); Sond., loc. supra cit., I I I (1850) : omn. pro parte. Mercurialis § Trismegista, Baill., loc. supra cit. quoad $M$. violaefoliam tantum (I862). Adenocline, Baill., loc. supra cit. (I858) ; Hook. f., loc. supra cit. (I868); Benth., loc. supra cit. (I880); Pax, loc. supra cit. (I890); omn. pro parte. Paradenocline, Müll. arg. in DC. Prodr., xv. 2, II 4 I.

I. A. violaefolia. Herba monoica. Folia ovata, acuta, basi minopere cordata, margine breve acute distanter serrata; stipulae lanceolatae, minutae.-Acalypha obtusata, Spreng. ex Steud., Nomencl., ed. 2, i. Io partim (I840). Mercurialis annua, Drège ex E. Mey. in Drège, Zwei Pfl. Documente, 201 (1843): nec Linn. M. tricocca, E. Mey., 1.c. sed quoad spp. partim tantum (I843), nomen; Eckl. et Zeyh. ex Krauss in Flora, xxviii. 85 (I845), nomen; Sond. in Linnaea, xxiii. III, syn. Thunb. excl. (1850). $M$. violaefolia, Kunze, Ind. Sem. Hort. Lips. MDCcCxLvi c. diagn. (1846), et in Linnaea, xx. 55 (1847) et xxiv. I62 (185I); Baill., Adansonia, iii. I59, syn. Thunb. excl. (1862). Adenocline Mercurialis, Baill., Etud. gén. Euphorb., 457, sed quoad spp. partim tantum (I858), nomen: nequaquam $A$. Mercurialis, Turcz. A. procumbens, [Benth. ex] Pax in Engl. \& Prantl, Nat. Pflanzenf., iii. 5, 49 (1890). Paradenocline violaefolia, Müll. arg. in DC. Prodr., xv. 2, 793 (1866), nomen. P. procumbens, Müll. arg., 1. c., 793, II4I (I866) : nequaquam Mercurialis procumbens, Linn. 
[VII a.] South-EASt Africa : Cape. Central region: Willowmore Div.; between $Z$ wartberg and Aasvogelberg, Drège (M. tricocca a in Herb. Brit. Mus.)! Graaf Reinet Div.; Oudeberg Mountains, 3,000 ft., and near Graaf Reinet, 2,500 ft., Bolus, 429!

Coast Region: Clanwilliam Div.; Zeekoe Vley, $400 \mathrm{ft}$., Schlechter, 8502 ! near Zwartbosch Kraal, 400-500 ft., Schlechter, 5174! Malmesbury Div.; Kloof near Hopefield, Bachmann, I265! pass near Malmesbury, 900 ft., Schlechter, 1603 ! Paarl Div.; near Paarl, I,oco ft., Drège (M. annua)! Cape Div.; Green Point, Zeyher, 3842 in part! Harvey! Waterfall on Devil's Mountain, Harvey! Constantia, 800-I,000 ft., Krauss, I82I ; Oatland's Point, Wolley Dod, 2922 ! Muizenberg, Schlechter, 1278! Swellendam Div.; Kinko River, near Swellendam, Zeyher, $3^{842}$ in part! Uitenhage Div.; Addo, Drege, 2346 ( $M$. tricocca, $\gamma$ )! Alexandria Div.; Zuurberg, Drige ( $M$. tricocca $\beta$ in part)!

Very different from the remaining species of the genus, but in general facies closely resembling Leidesia obtusa.

$\S 2$. Diplostylis. Caules herbacei, basi perennantes ibique sublignosi. Folia membranacea saepissime alterna et breve petiolata vel subsessilia, raro (A. acuta) opposita longe petiolata. Inflorescentiae I-sexuales. Antherarum loculi adscendentes.-Acalypha, Thunb. partim, loc. supra cit. (1823); Spreng. partim, loc. supra cit. (1840); nec Royen. Adenocline, Turcz., loc. supra cit. (I843, I844 et I85I); Baill., loc. supra cit. syn. 〈A. Mercurialis excl. (I 858); Müll. arg., loc. supra cit. (I866); Hook. f., loc. supra cit. (1868); Benth., loc. supra cit. syn. (Paradenocline excl. (I880); Pax, loc. supra cit. syn. 〈Paradenocline excl. (1890). Mercurialis, Meissn., loc. supra cit. (1843); Krauss, loc. supra cit. syn. Eckl. et Zeyh. excl. (1845); Kunze partim, loc. supra cit. (I847). Mercurialis $\S$ Adenocline, Baill., loc. supra cit. (1862). Diplostylis, Sond., loc. supra cit. (1850).

2. A. acuta, Baill., Etud. gén. Euphorb., 457 (I858); Müll. arg. in DC. Prodr., xv. 2, II4I (I866) ; Pax in Engl. et Prantl., Nat. Pflanzenf., iii. 5, 49, fig. $30 \mathrm{~A}-\mathrm{D}$ (I890). Herba dioica. Folia omnia longe petiolata, opposita, ovata, acuta, crenata vel serrata; stipulae laceratae.-Acalypha acuta, Thunb., Fl. Cap., ed. Schult., 546 (1823); Spreng. ex Steud., Nomencl., ed. 2, i. 9 (1840). Adenocline Mercurialis, Turcz. in Bull. Soc. Imp. Nat., Mosc., xvi. I, 60 (I843), et xxv. 2, I79 (I852); Flora, xxvii. I 2 I. (I844). A. panciflora, Turcz. 11. cc. quoad Drège 344I of (I 843, I 844 et $185_{2}$ ); Baill. Etud. gén. Euphorb., 457, partim (1858). Mercurialis caffra, $\alpha$ longipes et $\beta$ brevipes, Meissn. in Hook. Lond. Journ. Bot., ii. $55^{8}$ (I843); Krauss in Flora, xxviii. 84 (1845). M. Dregeana, Meissn., 1. c., 559 (1843); Krauss, 1.c. (I845). M. subcordata, Buching. ex Krauss, 1. c. (1845). M. pauciflora, Baill., Adansonia, iii. I59, partim (I862). Diplostylis caffra, Sond. in Linnaea, xxiii. II5 (1850). 
[VI.] South-West AfRicA. Transvaal: Barberton ; Rimer's Creek, Thorncroft, 250! 5592! Highland Creek, 3,000 ft., Galpin, 84I ! Houtbosch, Rehmann, 5963! Shilouvane, Funod, 863 !

[VII a.] South-EAST Africa: Cape. Central Region: Somerset Div.; Somerset East, Scott Elliott, 643 ! Philipstown Div. ; near Philipstown, 2,000-3,000 ft., Ecklon \& Zeyher!

Coast Region: Stellenbosch Div.; Hottentots Holland, Zeyher, 3842 partly! Caledon Div.; Oaks, Prior! Swellendam Div.; Voormanbosch, Zeyher, 3842 partly! George Div.; forest near George, Prior! Outeniqua Mountains, Rehmann, 259! Knysna Div.; Gouwkamma, Krauss, II92! Ruigte Valley, Drìge, 2301 a! Groene Valley, Burchell, 5625! Humansdorp Div.; near the Kromme River, Drigge, 230r b! Uitenhage Div.; near the Van Stadens River, Drige, 2301 c! without precise locality, Thunberg! Masson! Port Elizabeth Div.; Baakens River, Burchell, 4339 ! Mrs. Paterson, 838! Algoa Bay at Cape Recief, Ecklon, 6II! Ecklon \& Zeyher, 37! Krakakamma Forests, Zeyher, 552! Ecklon, 828! Alexandria Div.; Olifants Hoek, Ecklon \& Zeyher, 36! Bathurst Div.; mouth of Great Fish River, Burchell, 3735 ! between Sunday River and Fish River, Thunberg! near Port Alfred, Schönland, 788! I544! Schlechter, 2732! Albany Div.; near Grahamstown, Bolton! Bolus, 268I! Penther, 914! Howison's Poort, Mrs. H. Hutton! Macowan, 318! Trapp's Valley, Miss E. Anstey, 9! Atherstone, Rogers, 330I! without precise locality, Miss Bozwker! Williamson! Macowan, 222! Fort Beaufort Div.; near Fort Beaufort, Ecklon \& Zeyher, 38 ! Stockenstroom Div.; Katberg, Shazw! East London Div.; Rattray, 128 ! 158 !

[VII b.] Natal. Transkei ; Kentani, I,500 ft., Umtata Convent, 495 ! Tembuland; Bazeia, 2,500 ft., Baur, 128! Perie Forest, Schönland, 85I ! Pondoland; woods near Port Donald, 3,500 ft., Tyson, I782! without precise locality, Bachmann, 803 ! Griqualand East; Maclear Div., near the River Chivenka, 4,300 ft., Bolus, 10285! Natal; Notote, Gerrard, 32! Ingoma, Gerrard \& McKen, II75! Mount Insizwa, Krook, 906! woods near Byrne, 3,000 ft., Wood, 1816! Zuurberg Bush, Wood, 1987! near Van Reenen, 5,200 ft., Schlechter, 6958! Umlaas, Krauss, 156 ! without precise locality, Gerrard, 545 ! Cooper, 3151 !

Adenocline acuta is the most widely distributed of the species in this genus. It is also the most readily distinguishable, owing to its uniformly opposite long-petioled leaves. Within the species it is possible to recognize two fairly distinct forms which correspond to the two varieties of Mercurialis caffra, Meissn., recognized by Meissner. The former, $M$. caffra, a brevipes, represents what originally was considered by Meissner to constitute the species $M$. caffra. The latter, $M$. caffra, $\beta$ longipes, Meissner at one time considered a distinct species, $M$. Dregeana. It is the latter plant which corresponds to Adenocline Mercurialis, Turcz., because it was based upon 
the same Drègean specimen. The plant which forms the original $M$. caffra, later M. caffra, a brevipes, is the same as that portion of Adenocline pauciflora, Turcz., which has opposite leaves. The two plants can be fairly easily sorted out in herbaria because $a$ brevipes usually dries to a straw-yellow or yellowish-green colour, whereas $\beta$ longipes, the original Adenocline Mercurialis, Turcz., dries green. But there is no other tangible differential character, for both forms vary in size of leaf, length of petiole, character of leaf-base, and toothing of the leaf-margin. As the only certain character is one that can hardly be expected to prove of value in the field no good purpose is served by the continued recognition of Meissner's two varieties.

3. A. stricta, Prain in Kew Bull., I9I2, 338. Herba dioica. Folia sessilia, alterna, oblonga vel oblongo-lanceolata, acute serrata; stipulae oblongae, foliiformes.

[VII a.] South-EAST AFrICA: Cape. Coast Region: Bredasdorp Div. ; Reitfontein Poort, 100-200 ft., Bolus, 8603! Schlechter, 9694!

A very distinct species readily distinguished by its sessile leaves and very large leafy stipules.

4. A. ovalifolia, Turcz. in Bull. Soc. Imp. Nat. Mosc., xvi. I, 60 (I843) et xxv. 2, I79 (I852); Flora, xxvii. I2I (I844). Herba dioica. Folia omnia breve petiolata, alterna, inferiora ovata, superiora ovatolanceolata, margine acute serrata; stipulae majusculae, foliaceae. - Trianthema debile, Spreng. ex Turcz., Bull. Soc. Imp. Nat. Mosc., xvi. I, 60 (1843). T. dubium, Spreng. ex Turcz., 1. c., xxv. 2, I79 (1852). Mercurialis serrata, Meissn. in Hook. Lond. Journ. Bot., ii. 557 (1843); Krauss in Flora, xxviii. 84 (1845). $M$. bupleuroides, Kunze in Linnaea, xx. 54, syn. M. Zeyheri excl. (I847) ; Baill., Adansonia, iii. I59, pro parte (I862); nec Meissn. Diplostylis serrata, Sond. in Linnaea, xxiii. Ir4, quoad Zeyher I5I6 et quoad Eckl. \& Zeyh. 39, partim (1850). Adenocline humilis, Baill., Etud. gén. Euphorb., 457 (I858); nec Turcz. A. pauciflora, $\beta$ ovalifolia, Müll. arg. in DC. Prodr., xv. 2, II39; $\delta$ bupleuroides, Müll. arg., 1. c., I I40 quoad Zeyher I 5 I6 tantum ; et $\epsilon$ serrata, Müll. arg., l. c., I I40 (I866).

[VII a.] South-EAst Africa : Cape. Coast Region: Cape Div.; Houtsbay, o-I 50 ft., Masson! Krauss, I I90; Bolus, I093! 7059! Schlechter, 958! Wolley Dod, I652! Harvey, 626! Sandhills on Cape Plats, Wolley Dod, I882! Simonstown, by Noah's Ark Battery, Wolley Dod, 28 I9 in part! Swellendam Div.; without precise locality, Mund (Ecklon \& Zeyher 39), partly! Riversdale Div.; Kaffir Kuils River, Stack (Zeyher, I5I6)! East

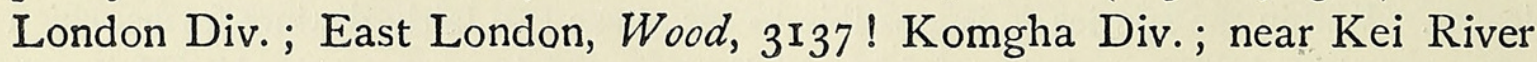
Mouth, Flanagan, 842 !

var. rotundifolia, Prain. Folia inferiora suborbicularia, superiora ovata, ceterum typi.-A. pauciflora, a rotundifolia, Müll. arg. in DC. Prodr., xv. 2, II 39 (I866). 
[VII a.] South-East Africa: Cape. Coast Region: Cape Div.; Simonstown, by Noah's Ark Battery, Wolley Dod, 2819 mainly! without precise locality, Forbes!

The variety perhaps hardly deserves recognition apart from the type.

5. A. humilis, Turcz. in Bull. Soc. Imp. Nat. Mosc., xvi I, 61 (1843) et xxv. 2, I72 sed ibi syn. Meissn. et syn. Sond. excl. (I $\left.85^{2}\right)$; Flora, xxvii. I 2 I (I 844). Herba dioica. Folia omnia breve petiolata, alterna, basalia orbiculari-cordata, superiora ovato-lanceolata, margine nunc crenata vel obscure serrata nunc integra; stipulae minimae, lanceolatae.-Adenocline pauciflora, Turcz., 1.c., xvi. I, 60, quoad spp. t foliis alternis (1843); Baill., Étud. gén. Euphorb., 457, partim (1858). Mercurialis tenella, Meissn. in Hook. Lond. Journ. Bot., ii. 556 (1843); Krauss in Flora, xxviii. 84 (1845). M. triandra, Sond. in Linnaea, xxiii. I I 3 , quoad syn. Meissn. (1850); Baill., Adansonia, iii. I60, partim et quoad syn. Meissn. (1862); nec E. Mey. M. pauciflora, Baill., 1. c., I59, partim (I862). M. bupleuroides, Baill., 1. c., partim (1862); nec Meissn. Adenocline pauciflora, $\gamma$ humilis, Müll. arg. in DC. Prodr., xv. 2, I I 40 syn. Kunze excl. (I 866), et $\theta$ tenella, Müll. arg., 1. c. (I866).

[VII a.] South-East Africa: Cape. Coast Region: Mossel Bay Div.; banks of Great Brak River, Burchell, 6I57! Humansdorp Div.; Zitzikamma, Krauss, II9I. Stockenstroom Div.; Katberg, Drège, 334I (male plant only)! 8223! Queenstown Div.; Hangklip Mountains, 6,000 ft., Galpin, I782!

Central Region: Graaf Reinet Div.; Cave Mountains, 4,400 ft., Bolus, 697 mainly! 4570 !

Closely resembles $A$. ovalifolia, but is readily distinguished by its smaller size and its minute stipules.

6. A. bupleuroides. Herba dioica. Folia alterna, inferiora orbicularia vel obovata, obtusa, breve petiolata, superiora ovato-lanceolata lanceolata vel linearia, acuta, sessilia, omnia margine acute serrata ; stipulae lanceolatae, foliaceae.-Mercurialis bupleuroides, Meissn. in Hook. Lond. Journ. Bot., ii. 557, quoad Krauss I1 69 tantum (I 843); Krauss in Flora, xxviii. 84 (I845); Kunze in Linnaea, xx. 54, syn. $M$. Zeyheri exclus. (1847) ; Baill., Adansonia, iii. I59, partim (1862). Diplostylis bupleuroides, Sond. in Linnaea, xxiii. II4, quoad Gueinzius 172 tantum (1850). [D. longifolia, Sond. MSS. in Herb. Harv. T. C. D.] Adenocline humilis, Turcz. in Bull. Soc. Imp. Nat. Mosc., xxv. 2, I 79, partim et quoad syn. Meissn. et syn. Sond. (I 852 ); nequaquam Turcz., 1. c., xvi. I, 61. A. pauciflora, $\delta$ bupleuroides, Müll. arg. in DC. Prodr., Xv. 2, II40, quoad Krauss I I69 et Gueinzius 172 tantum (I866).

[VII a.] South-EAST Africa: Cape. Coast Region: Uitenhage Div.; Elands River, Ecklon \& Zeyher, 39 partly! Albany Div.; near Grahamstown, Miss M. Daly, 903 ! Featherstone's Kloof, 2,500 ft., Galpin, 
255 ! East London Div.; near Nahoon, Rattray, 216! Komgha Div.; near the Gwenkala River, Flanagan, 695!

[VII b.] Natal. Griqualand East; Mount Currie, 5,300 ft., Tyson, I798! I833! Natal; near Durban, Gueinzius, I72! above Pinetown, 2,200 ft., Wood, 5003! Clairmont, Wood, $1_{06} 6$ ! Inchanga, 2,000-3,000 ft., Wood, 7184! Inanda, I;800 ft., Wood, 253 ! Tugela, Haygarth in Herb. Wood, IOI 55 ! Ingoma, Gerrard \& McKen, I 68 ! Nottingham, Buchanan, I49! near Krantz Kloof, I,500 ft., Schlechter, 3I79! Alexandra, Dumisa, 2,000 ft., Rudatis, 634! Zululand ; Entumeni, 2,000 ft., Wood, 74I !

var. Peglerae. Folia superiora quae sessilia cum inferioribus petiolatis orbicularia vel obovata, obtusa.

[VII b.] South-East Africa: Natal. Transkei; Kentani, Miss Pegler, 87 I !

7. A. Zeyheri. Herba dioica. Folia alterna, omnia lanceolata margine parce serrata, inferiora breve petiolata, superiora sessilia ; stipulae lanceolatae, foliaceae.-Adenocline sessilifolia, Turcz. in Bull. Soc. Imp. Nat. Mosc., xvi. I, 6I quoad Drège I 867 tantum (I843), nec Turcz., 1. c., xxv. 2, I 80 . A. serrata, Turcz., 1. c., xxv. 2, 180 syn. excl. (1852). A. pauciflora, $\gamma$ humilis, Müll. arg. in DC. Prodr., xv. 2, I 140, quoad syn. 〈Mercurialis Zeyheri tantum (I 866); $\delta$ bupleuroides, Müll. arg., 1. c., quoad Drège I 867 tantum (I866); et $\zeta$ transiens, Müll. arg., 1. c. (1866). Mercurialis bupleuroides, Meissn. in Hook. Lond. Journ. Bot., ii. 557, quoad Drège 1867 tantum (1843); Kunze in Linnaea, xx. 54, quoad syn. M. Zeyheri (1847); Baill., Adansonia, iii. I59, partim (1862). M. Zeyheri, Kunze, 1. c. (1847). Diplostylis serrata, Sond. in Linnaea, xxiii. I I4, excl. Zeyher I 516 .(I850).

[VII. a.] South-East Africa: Cape. Central Region: Graaf Reinet Div.; near Graaf Reinet, 4,000 ft., Bolus, 697 partly!

Coast Region: Knysna Div.; between Groene Valley and $Z_{\text {wart }}$ Valley, Burchell, 5678! Humansdorp Div.; Humansdorp, Rogers, 3082! Uitenhage Div.: sand dunes near Uitenhage, Ecklon \& Zeyher, 39 partly! Port Elizabeth Div.; near Port Elizabeth at Walmer and Humewood, Mrs. Paterson, I030! Albany Div.; Grahamstown, South! Howison's Poort, 2,000 ft., Glass, I9I! Without precise locality, Drège, I867 a! 1868 partly!

This species is nearest, as Kunze originally suggested, to $A$. bupleuroides, but is most readily mistaken for $A$. sessilifolia. It is, however, easily distinguished, when carefully examined, from both.

8. A. sessilifolia, Turcz. in Bull. Soc. Imp. Nat. Mosc., xvi. I, 6I, quoad Drège I 868 tantum (I 843 ) et xxv.2, I 80 (I $\left.85^{2}\right)$; Flora, xxvii. I $2 \mathrm{I}$, pro parte (1844). Herba dioica. Folia alterna, inferiora anguste lanceolata, breve 
petiolata, superiora lineari-lanceolata, sessilia, omnia margine integra; stipulae lineares.-Diplostylis angustifolia, Sond. in Linnaea, xxiii. II 3 (1850). Adenocline sessiliflora, Baill., Etud. gén. Euphorb., 457, t. 9, fig. 6 (I858). Mercurialis bupleuroides, Baill., Adansonia, iii. I59, pro parte (I862); nec Meissn. Adenocline panciflora, $\eta$ sessilifolia, Müll. arg. in DC. Prodr., xv. 2, II 40 (1866). A. pauciflora, Pax in Engl. \& Prantl, Nat. Pflanzenf., iii. 5,49 fig. $30 \mathrm{E}$ (I890); nec Turcz.

[VII a.] South-East Africa : Cape. Coast Region: Clanwilliam Div.; Brakfontein, Ecklon \& Zeyher, 40! Malmesbury Div.; between Mamre and Saldanha Bay, Drège, I868! Cape Div.; Riet Valley, near Laudenbach, Ecklon \& Zeyher, 39 partly! Uniondale Div.; near Avontuur, Bolus, 2460 !

A very distinct species.

\section{Distribution of Seidelia, Leidesia, and Adenocline.}

In the enumeration of the species of these three endemic South African genera, the geographical area of each, so far as this is known, has been stated in accordance with the subdivision of the African continent adopted for the genera Erythrococca and Micrococca in an earlier paper (Ann. Bot., xxv. 632-4). All the species of the three genera here dealt with are confined to the south of the tropic of Capricorn, and are met with only in the areas VI and VII of the previous paper. They, therefore, occur only in the catchment area of the Orange-Vaal or to the south and south-east of that catchment area, or in both of these regions.

The South-eastern Region it was found convenient to divide into a western, or Cape, half from the Kei River westward, and an eastern, or Natal, half to the east of that stream. In the present instance it is convenient to subdivide the South-western Region into a western or Namaqualand half, and an eastern or Transvaal-Griqualand half.

In the Namaqua portion of South-West Africa only one species, Leidesia firmula, is found; the species is there endemic. In the eastern half of SouthWest Africa three species are met with: Seidelia triandra, Leidesia procumbens, and Adenocline acuta. Only the first of these three is endemic; the two others are cases of overflow from the Cape portion of South-East Africa.

In the Eastern or Natal half of South-East Africa we again find three species, two of which, occurring only as overflows from the Cape portion of South-East Africa, are Leidesia procumbens and Adenocline acuta, species which also overflow into the Transvaal. The third Natal species, Adenocline bupleuroides, though not endemic, is almost as distinctive of Natal as Seidelia triandra is of Griqualand; it only extends as an overflow into the Cape region proper for some little distance to the west of the Kei River. 
4 Io Prain.-Mercurialineae and Adenoclineae of South Africa.

We find, then, that three of our four areas, Namaqua, Griqua, and Natal, have each one distinctive species, but that the species which is distinctive of Natal overflows westward into the Cape area proper. On the other hand, this Cape area, though exhibiting no overflow into Namaqua, does show an overflow into Natal and into the Transvaal by means of Leidesia procumbens and Adenocline acuta. In the Cape region itself there are eight other species, all of them endemic ; the endemic Cape element is thus 72 per cent. of the whole. The details of this distribution are shown more succinctly in the subjoined conspectus, wherein overflow species are marked $(x)$, introduced species $[x]$.

Conspectus of the Distribution of the South African MERCURIALINEAE AND ADENOCLINEAE.

\begin{tabular}{|c|c|c|c|c|c|}
\hline \multirow{2}{*}{\multicolumn{2}{|c|}{ Species. }} & \multicolumn{2}{|c|}{ VI. Sonth-West Africa. } & \multicolumn{2}{|c|}{ VII. South-East Africa } \\
\hline & & Namaqua. & Griqua-Vaal. & Cape. & Natal. \\
\hline | & $\left\{\begin{array}{l}\text { Mercurialis annua. } \\
\text { Seidelia triandra : } \\
\text { Leidesia obtusa. } \\
\text { " procumbens: } \\
" \text { firmula. }\end{array}\right.$ & $\begin{array}{l}\overline{-} \\
\overline{-} \\
\bar{x}\end{array}$ & $\begin{array}{l}\bar{x} \\
\bar{x} \\
\bar{x})\end{array}$ & $\begin{array}{c}{[x]} \\
-x \\
x \\
x \\
-\end{array}$ & $\overline{\overline{-}} \overline{\bar{x}}$ \\
\hline \multirow[t]{2}{*}{ 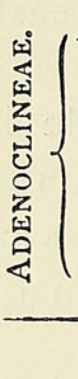 } & $\left\{\begin{array}{cl}\text { Adenocline violaefolia } \\
\text { ", } & \text { acuta } \\
", & \text { stricta } \\
", & \text { ovalifolia. } \\
", & \text { humilis } \\
\text { ", } & \text { bupleuroides } \\
\text { ", } & \text { Zeyheri } \\
\text { ", } & \text { sessilifolia. }\end{array}\right.$ & $\begin{array}{l}\bar{z} \\
\overline{-} \\
\bar{z} \\
\bar{z}\end{array}$ & $\begin{array}{l}\overline{(x)} \\
\overline{-} \\
\overline{-} \\
\overline{-}\end{array}$ & $\begin{array}{l}x \\
x \\
x \\
x \\
x \\
(x) \\
x \\
x\end{array}$ & $\begin{array}{l}\bar{x}) \\
\overline{-} \\
\bar{x} \\
\overline{-}\end{array}$ \\
\hline & Totals . & I & 3 & 12 & 3 \\
\hline
\end{tabular}




\section{$2 \mathrm{BHL}$ Biodiversity Heritage Library}

Prain, D. 1913. "The Mercurialineae and Adenoclineae of South Africa." Annals of botany 27, 371-410. https://doi.org/10.1093/oxfordjournals.aob.a089467.

View This Item Online: https://www.biodiversitylibrary.org/item/237410

DOI: https://doi.org/10.1093/oxfordjournals.aob.a089467

Permalink: https://www.biodiversitylibrary.org/partpdf/319980

\section{Holding Institution}

Smithsonian Libraries

\section{Sponsored by}

Biodiversity Heritage Library

\section{Copyright \& Reuse}

Copyright Status: Not in copyright. The BHL knows of no copyright restrictions on this item.

This document was created from content at the Biodiversity Heritage Library, the world's largest open access digital library for biodiversity literature and archives. Visit BHL at https://www.biodiversitylibrary.org. 